\author{
Marquette University \\ e-Publications@Marquette
}

3-2018

\title{
Resilience Portfolios and Poly-Strengths: Identifying Protective Factors Associated with Thriving After Adversity
}

Sherry L. Hamby

Sewanee: The University of the South

John H. Grych

Marquette University, john.grych@marquette.edu

Victoria Banyard

University of New Hampshire

Follow this and additional works at: https://epublications.marquette.edu/psych_fac

Part of the Psychology Commons

\section{Recommended Citation}

Hamby, Sherry L.; Grych, John H.; and Banyard, Victoria, "Resilience Portfolios and Poly-Strengths: Identifying Protective Factors Associated with Thriving After Adversity" (2018). Psychology Faculty Research and Publications. 349.

https://epublications.marquette.edu/psych_fac/349 
Marquette University

e-Publications@Marquette

\section{Psychology Faculty Research and Publications/College of Arts and Scuences}

This paper is NOT THE PUBLISHED VERSION; but the author's final, peer-reviewed manuscript. The published version may be accessed by following the link in th citation below.

Psychology of Violence, Vol. 8, No. 2 (March 2018): 172-183. DOI. This article is (C) American Psychological Association and permission has been granted for this version to appear in ePublications@Marquette. American Psychological Association does not grant permission for this article to be further copied/distributed or hosted elsewhere without the express permission from American Psychological Association.

\section{Resilience Portfolios and Poly- Strengths: Identifying Protective Factors Associated With Thriving After Adversity}

\section{Sherry Hamby}

Life Paths Appalachian Research Center, Monteagle, Tennessee, and Department of Psychology, University of the South;

\section{John Grych}

Department of Psychology, Marquette University

\section{Victoria Banyard}

Department of Psychology, University of New Hampshire

Acknowledgement: This work was made possible through the support of a grant from the John Templeton Foundation. The opinions expressed in this article are those of the authors and do not necessarily reflect the views of the John Templeton Foundation. 
Note: Maureen C. McHugh served as action editor for this article.-SH

Efforts to understand resilience in victims of adversity developed as a counterpoint to the heavy emphasis of psychological research on mental health problems resulting from exposure to stress and trauma (Grych, Hamby, \& Banyard, 2015; Masten, 2014). Progress has been made in identifying protective factors associated with more positive outcomes following adverse experiences, but this research remains limited in several respects, including tendencies to operationalize healthy outcomes as low levels of symptoms and to assess protective factors that simply represent the inverse of risk factors. We use a framework called the resilience portfolio model (Grych et al., 2015) to seek a more comprehensive understanding of how individuals survive and even thrive after experiencing adversity. This model integrates work on resilience with research on positive psychology, posttraumatic growth, and coping to identify factors that could contribute to health and well-being following exposure to stressful and traumatic events. In this study, we examine multiple potential protective factors with the aim of identifying which protective factors hold the most potential for helping people thrive after adversity. We also explore the utility of a new concept, poly-strengths, which is an indicator of the density and diversity of a person's overall portfolio of strengths. Finally, we evaluate these protective factors with positive indicators of well-being as well as symptomatology.

\section{Defining Resilience}

Resilience involves three elements. One, an adversity-some sort of stressful or traumatic experience-must occur. Two, there must be some evidence of healthy functioning after the adversity. The final element is the mechanism(s) by which the usual distress is avoided or recovered from-the protective factor or strength that allows one to rebound from an adversity (for further discussions of the concept of resilience, see Bonanno, 2004; Luthar, Cicchetti, \& Becker, 2000; Masten, 2001). Although theorists have defined domains of competence that serve as indicators of resilience (e.g., Luthar et al., 2000; Masten, 2014), many empirical studies ostensibly examining resilience have measured functioning strictly in terms of low levels of clinical symptoms or the absence of psychological distress. A recent review of research on resilience in children exposed to violence found that two thirds of the studies included a measure of behavior problems as the sole outcome measure, with resilience being equated to low scores on the measures of symptoms or behavior problems (Houston \& Grych, 2015). Health is not simply the absence of pathology, and the importance of assessing indicators of well-being in addition to clinical symptoms has been emphasized by several theorists (Diener, Emmons, Larsen, \& Griffin, 1985; Keyes, 2007; Lyubomirsky, King, \& Diener, 2005). Existing empirical studies incorporating measures of well-being along with clinical symptoms have shown that these distinct outcomes can have different correlates (e.g., Antaramian, Scott Huebner, Hills, \& Valois, 2010; Keyes, 2007).

\section{Research on Protective Factors Associated With Resilience}

The study of resilience has led to efforts to identify "protective factors" that predict better adjustment in individuals who have experienced adversity (Bonanno, 2004; Fergusson \& Horwood, 2003; Luthar et al., 2000). Research on protective factors can help identify the most helpful targets for prevention and intervention and go beyond self-report measures that simply ask people to report on whether or not they perceive themselves as resilient. Several protective factors have been identified, such as 
emotional regulation and social support. This research has provided valuable insights, but is limited in certain key ways. First, many of these protective factors represent the opposite pole of established risk factors and may not provide unique information about the processes that promote resilience (e.g., Masten \& Tellegen, 2012). For example, parental warmth is positively related to better health outcomes, but this association may simply represent the inverse of the frequently documented association between parental rejection and negative health outcomes. Thus, there is a need to identify protective factors that are distinct from indicators of risk. Second, some variables identified as protective factors in resilience research are static variables (e.g., gender, ethnicity) that do not have risk or protective effects in and of themselves; they are markers for other processes, such as differences in roles, differences in access to services, differences in the experience of discrimination and other elements that explain the variations in these groups (Hamby, 2015). Further, personal characteristics such as gender and ethnicity are not ready targets for intervention or prevention. Finally, there are few conceptual frameworks that organize the wide range of protective factors into a coherent model (Sabina \& Banyard, 2015), and consequently much of the work on protective factors has been atheoretical.

\section{Resilience Portfolio Model}

The resilience portfolio model (Grych et al., 2015) integrates theory and research on resilience, positive psychology, posttraumatic growth, and coping in an effort to provide a more comprehensive understanding of the processes that promote health and thriving in individuals exposed to adversity. We drew on the resilience literature to identify protective factors consistently associated with adaptive functioning. From the field of positive psychology, we integrated character strengths associated with well-being into the model (e.g., Peterson \& Seligman, 2004). These strengths have often been organized into higher-order categories that reflect common themes or functions (e.g., Peterson, Park, Pole, D’Andrea, \& Seligman, 2008; Peterson \& Seligman, 2004), and in the resilience portfolio model we organized strengths into three functional domains: self-regulation, interpersonal strengths, and meaning-making. For each, we focused on malleable factors that have the potential to be targeted by prevention and intervention efforts. A goal of the resilience portfolio model is to integrate these varied factors and components, which historically have been studied in isolation, into a more comprehensive model (Lenzi et al., 2015).

Regulatory strengths foster the capacity to control impulses, manage difficult emotions, and persevere in the face of setbacks and are some of the individual strengths that have long been singled out as particularly important for resilience (Masten, 2007; Masten et al., 2004; Moffitt et al., 2011). For example, emotion regulation predicts better outcomes in children exposed to family (e.g., Cicchetti, Rogosch, Lynch, \& Holt, 1993) and community violence (e.g., Kliewer et al., 2004). Several character strengths studied in the positive psychology literature also can promote self-regulation, including perseverance and grit (Duckworth, Steen, \& Seligman, 2005).

The second domain includes interpersonal relationships (including family, friends, and neighbors) and personal qualities that sustain these relationships. Supportive relationships and the ability to initiate and maintain strong relationships among families, friends, and communities support resilience and thriving. Social support is a well-established protective factor (for a review, see Thoits, 2011) and several strengths identified in the positive psychology literature function to strengthen interpersonal 
connections (e.g., generosity, compassion, forgiveness). The interpersonal domain also captures broader elements of a person's social-ecological niche (Bronfenbrenner, 1986), including features of communities, cultures, and other elements of one's social network.

Finally, meaning-making represents individuals' ability to explain and understand their experiences. Research on resilience, positive psychology, and posttraumatic growth all propose that the capacity to find meaning in difficult and even traumatic life events promotes mental health (e.g., Lyubomirsky, 2001; Masten, 2007; Tedeschi \& Calhoun, 1996). This category includes religious and spiritual meaning making, which is a key way that many people cope with violence and other adversity (Hamby, 2014), but also incorporates secular approaches to meaning making, including a sense of purpose and hope.

Increasingly, culture and context have been explored as important facets of resilience (Ungar, 2013), and in the resilience portfolio model are represented by constructs such as community support in the interpersonal domain. Most of the best-known research on communities and neighborhoods has been conducted in cities such as Chicago or Nashville (Chavis \& Wandersman, 1990; De Marco \& De Marco, 2010; Sampson, Raudenbush, \& Earls, 1997). Appalachia is a particularly understudied area of the United States and is also one of the most vulnerable regions in terms of poverty, poor health outcomes, and related factors (Kennedy, Davidov, \& Burrell, 2014). The current study presents an opportunity to further understand resilience in one of the largest and most vulnerable regions of the United States.

\section{Poly-Strengths}

No one is good at everything, and one reason we chose the term "portfolio" for the Resilience Portfolio Model is the idea that people need a range of strengths to reduce their exposure and improve their coping with adversity. Further, just as in a financial portfolio, there are probably a range of different combinations that effectively promote resilience (e.g., Lenzi et al., 2015). We use the term polystrengths to refer to the total number of protective factors that an individual possesses. The term is analogous to poly-victimization, or the cumulative burden of all types of violent experiences (Finkelhor, Shattuck, Turner, Ormrod, \& Hamby, 2011). The assessment of poly-victimization has shown that it is the total burden, more than any one type of victimization, that is most associated with psychological outcomes. In parallel fashion, it is possible that it is the total number of strengths in individuals' "portfolio" that is critical for promoting healthy functioning, rather than any particular strength. We tested whether poly-strengths is a unique predictor of functioning, and whether there are strengths that account for unique variance in adaptation even after accounting for the total number of strengths.

\section{The Current Study}

Guided by the resilience portfolio model, the present study investigated the following questions. We hypothesized that individual strengths would have positive associations with each outcome and that poly-strengths would account for unique variance in outcomes after accounting for adversities and other strengths. The current study is based in rural Appalachia, a low-income area, but one with underappreciated strengths and where strengths-based approaches and portrayals have been particularly lacking (Hamby, Segura, Taylor, Grych, \& Banyard, in press). Given the scarcity of analyses examining multiple strengths, we also explored whether any specific strengths were still uniquely associated with positive outcomes after accounting for adversities, poly-strengths, age, sex, and other 
protective factors. We also expanded the assessment of outcomes by including three indicators of healthy functioning: subjective well-being, posttraumatic growth, and mental health symptoms, and assessing these in terms of thriving (above-average functioning), not just the absence of distress. The findings can contribute to guidance about which strengths are best targeted in prevention and intervention programs.

\section{Method}

\section{Participants}

Participants were 2,565 participants from the Appalachian region of three Southern states. The sample was $63.9 \%$ female. The sample included adolescents and adults age 12 and over, with an average age of 30.0 years $(S D=13.2$ ) and a median of 27 . Educational status included $18.1 \%$ who were still in middle or high school, $34.8 \%$ who had a high school diploma or equivalent, $7.2 \%$ with less than a high school education (and not currently in school), 18.6\% with some college but no degree, $8 \%$ with an associate's degree, $7.9 \%$ with a bachelor's degree, and $5.4 \%$ with more than a bachelor's degree. Almost 2 in 5 (39.2\%) of the sample reported household income less than $\$ 20,000$ per year, 36\% earned $\$ 20,000$ to $\$ 50,000$, and $24.9 \%$ of the sample earned more than $\$ 50,000$ per year. More than a $1 / 3$ of the sample (35.6\%) receives some form of public assistance. The sample identified as $75.6 \%$ White/European American (non-Latino), 12\% Black/African American (non-Latino), 6.4\% Latino (any race), 1.2\% American Indian/Alaska Native, 0.6\% Asian, 0.3\% Pacific Islander, and 3.9\% multiracial.

\section{Measures}

Development and validation of measures in pilot study and this sample

Given that our sample included significant numbers of young adolescents and people with limited educational attainment, it was essential that the reading level be appropriate for all participants. Brevity was also a priority. We simplified and adapted items from existing questionnaires and wrote new items for constructs for which no suitable measure could be found.

To establish reliability and validity for new and adapted items, we conducted a pilot study with 108 participants from the same community as the main sample, recruited through a local email classifieds list and word-of-mouth. Reliability and validity were further examined in this sample. Internal consistencies for the pilot averaged .81 (range .58 to .95) and improved to an average of .84 in the main sample (range .63 to .94). Validity was established in the pilot and main samples with moderate correlations with related constructs. Factor analysis in the main sample was also used for further item reduction and clarifying of constructs. Further details on each measure are below. Unless specified, response categories were on a 4-point Likert scale with 1 denoting not true about meand 4 denoting mostly true about me. Standardizing response categories across items reduces the respondent burden, shortens survey time, minimizes method variance, and is common for large scale community surveys (e.g., Finkelhor et al., 2011). Missing data were imputed based on responses to other items on same scale. In all cases, higher scores represent higher levels of strengths, psychological functioning, and adversity. See http://lifepathsresearch.org for complete scales and further details on measure development. More information on measurement development is also available in (Hamby, Grych, \& Banyard, 2013). 
Adversities included three broad domains - interpersonal victimization, other adverse life events, and financial strain. The Juvenile Victimization Questionnaire-Key Domains Short Form includes 21 items assessing lifetime history of a range of interpersonal victimizations (adapted from Hamby, Finkelhor, Ormrod, \& Turner, 2004). A sample item is "During your childhood, did one of your parents get hit or pushed by another parent?" Dichotomous items ("yes" or "no") were summed to create a total victimization score. Adverse Life Events is an 11-item scale adapted from the National Survey of Children's Exposure to Violence (Turner, Shattuck, Hamby, \& Finkelhor, 2013) measuring the types of major life challenges one has experienced. Responses were dichotomous, and "yes" answers were summed to create a total score. A sample item is "Did you ever have anyone close to you die because of an illness or an accident?" Because endorsing one event does not necessarily imply experiencing another event, no internal consistency is reported. Financial Strain contains five items assessing perceived economic pressure (Hamby, Turner, \& Finkelhor, 2011). A sample item is “You don't have enough money to pay regular bills." Participants responded on a 3-point Likert scale ranging from not true to very true.

Regulatory strengths assess various aspects of self-control, especially when confronting difficulties. Emotional Regulation comprises four items assessing one's ability to manage distressing feelings, adapted from the DERS (Gratz \& Roemer, 2004). A sample (reverse-scored) item is "When I'm upset, I feel out of control." Emotional Awareness was assessed with two items on the ability to monitor one's own feelings adapted from the DERS (Gratz \& Roemer, 2004). A sample item is "I am aware of my feelings." The Psychological Endurance Scale (Hamby et al., 2013) uses six items to assess one's ability to persevere despite challenges. Sample items are "I am a source of strength to my family" and "I am quick to pick myself up when I get "knocked down." The Anger Management Scale-Brief Trait version (Hamby, Stith, Grych, \& Banyard, 2013) includes five items on the ability to control one's temper adapted from Stith and Hamby's (2002)partner-specific scale. A sample item is "I can calm myself down when I am upset." Honesty used two items adapted from the HEXACO-PI-R (Ashton \& Lee, 2009) to assess ethical behavior. A sample (reverse-scored) item is "If I knew that I could never get caught, I might be willing to steal." The Coping Scale (Hamby et al., 2013) used 13 items to assess behavioral and cognitive-emotional responses for dealing with adversity (adapted from Holahan \& Moos, 1987 and Spitzberg \& Cupach, 2008). A sample item is "When dealing with a problem, I spend time trying to understand what happened."

Meaning-making constructs assess ways that individuals seek spiritual and personal fulfilment. The Purpose scale includes two items from the Meaning in Life Questionnaire (Steger, Frazier, Oishi, \& Kaler, 2006) and one item from the Life Orientation Test (Scheier, Carver, \& Bridges, 1994) that assess perceptions that there is a reason for existence. A sample item is "I have a good sense of what makes my life meaningful." For optimism, two items from the Life Orientation Test (Scheier et al., 1994) measure positive expectancies in their lives: "If something can go wrong for me, it will" and "I hardly ever expect things to go my way." (Hamby et al., in press) The Meaning-Making Questionnaire includes four subscales. Meaning-Making-Relationship-oriented includes 10 items on how individuals help others to make their own lives meaningful. A sample item is "I work hard to be an active member of my community." Meaning-Making-Self-oriented is nine items on improving one's mental and physical well-being. A sample item is "I spend time each week learning something new." Meaning-MakingMorals assesses adherence to standards of beliefs and behaviors in respondents' daily lives (four 
items). A sample item is "I make sure that each day I am doing the right thing." Meaning MakingFamily Care comprises five items measuring caregiving and work on strengthening family ties. A sample item is "I take care of older or younger family members each week." The Religious Meaning Making scale consists of 11 items (Amato, 1990; Levin, Markides, \& Ray, 1996; Pargament et al., 1998; Putney \& Middleton, 1961) assessing engagement in religious and spiritual practices. A sample item is "My faith or spiritual beliefs affect my views on other things."

Interpersonal strengths include the participants' relational skills and also indicators of support from their larger social environment. Community Support comprises nine items assessing the degree to which one's neighbors get along and help one another (adapted from Sampson, Raudenbush, \& Earls, 1997; U.S Air Force, 2011). A sample item is "People in my neighborhood offer help to one another in times of need." Compassion consists of nine items assessing how one engages with others in a caring, concerned, and helpful way (adapted from McCullough, Emmons, \& Tsang, 2002; Pommier, 2011; Sprecher \& Fehr, 2005). A sample item is "When others feel sad, I try to comfort them." Maternal Attachment comprises six behavioral indicators of a close and secure relationship with one's mother or mother figure, adapted from the Attachment Behaviors Scale (Furman \& Buhrmester, 2009). A sample item is "You seek out your mother (or mother figure) when you're upset." Paternal Attachment contains parallel items to maternal attachment that ask about one's father or father figure. A sample item is "Your father (or father figure) shows support for the things you do." Forgiveness consists of three items assessing one's ability to move on following an argument (adapted from the partner-specific scale developed by Gordon \& Baucom, 2003). A sample item is "I am ready to put what happened behind me." For Generativity, five items were adapted from the Loyola Generativity Scale-Short Form (McAdams \& de St. Aubin, 1992) measuring one's concern for guiding future generations. A sample item is "I like to teach things to people." Social Support-Immediate Family comprises six items that assess the extent to which individuals' family members serve as sources of strength and guidance (adapted from Turner, Finkelhor, \& Ormrod, 2010; Zimet et al., 1988). A sample item is "I can talk about my problems with my family." Social Support-Friends and Adults contains six items measuring the extent to which individuals' friends and nonparent adults serve as sources of strength and guidance (adapted from Turner, Finkelhor, \& Ormrod, 2010). A sample item is "I can talk about my problems with my friends." Generous Behaviors are assessed by a six-item scale that measures last year giving activities (Hamby et al., 2013; adapted from Amato, 1990). Items were dichotomous ("yes" or "no"). A sample item is "Spent time volunteering at a charity." Generative Roles comprise nine items assessing specific roles through which one has guided and served future generations (Hamby et al., 2013). Items were dichotomous ("yes" or "no"). A sample item is "I have been a schoolteacher."

We defined poly-strengths as the total number of strengths that each individual reported at above average levels (>.5 SD). In this sample, the range was from 0 to 23 (total number of protective factors we surveyed), with a mean of 8.95 (SD 5.28) and a mode of 8.

A range of outcomes was examined. Thriving for each outcome was scored as $\geq .5$ standard deviations above the mean for standardized scores. We focused on thriving to emphasize the well-being end of the spectrum for these measures. Higher scores for each measure indicate better functioning. Subjective Well-Being is assessed with five items from the Satisfaction with Life Scale (Diener et. al., 
$\underline{1985)}$ that measure a person's perception of how well their life is going. A sample item is "I am satisfied with my life." Post-Traumatic Growth is measured by 10 items from the Posttraumatic Growth Inventory (Tedeschi \& Calhoun, 1996) on increased self-awareness and appreciation of life following adversity (referencing the most stressful event in the last year). A sample item is "Now I know that I can handle hard times." Mental Health is measured by 10 psychological symptoms adapted from the Trauma Symptom Checklist-Youth (Briere, 1996) assessed on a 4-point scale ranging from never to almost all the time. A sample item is "Feeling lonely in the last month." The scale was reverse-scored; higher scores indicate fewer symptoms.

\section{Procedure}

Participants were recruited through a range of advertising techniques. The majority of participants (76\%) were recruited at local community events, such as festivals and county fairs. Word-of-mouth was the second most productive recruitment strategy, accounting for $12 \%$ of participants. The remaining $12 \%$ were recruited through other strategies, including flyers, newspaper and radio ads, and direct mail. This wide range of recruitment strategies allowed us to reach segments of the population who are rarely included in psychology research. Interviewers offered to meet participants in multiple locations throughout the community (including our research center, other campus locations, and their homes), during daytime or evening hours. This flexibility provided people with limited availability or transportation an opportunity to participate. This region of Appalachia still has limited and sometimes unreliable cellular and Internet service; therefore, the survey software was specifically chosen to operate without Internet connectivity. The survey was self-administered using Snap10 survey software on laptops and iPads. An audio option was available. Technical problems (such as iPads overheating) and time limitations prevented some individuals from completing the survey; overall, the completion rate was $85 \%$ and the median completion time was $53 \mathrm{~min}$. This is an excellent result by current survey standards, especially considering the survey length, with current completion rates often under $70 \%$ (Abt SRBI, 2012) and sometimes under 50\% (Galesic \& Bosnjak, 2009). Income and educational patterns are similar to the region as a whole, and our sampling strategy successfully recruited somewhat higher percentages of African American and Latino American respondents. All participants received a $\$ 30$ Walmart gift card and information on local resources. All procedures were conducted in accordance with American Psychological Association (APA) ethical principles and approved by the institutional review board of the study's home institution.

\section{Results}

First, we characterize the sample in terms of victimization and adversity experiences, financial strain, and their self-reported strengths. Then, we present the multivariate analyses for each of the outcome variables.

\section{Prevalence of Victimization and Other Adversities}

\section{Victimization}

The participants in this sample reported high rates of all adversities assessed in our study. As seen in Table 1, four forms of peer and witnessing victimization were reported by more than half of the sample and all types of peer and nonfamilial witnessing victimization were reported by more than 1 in 3 participants (range is $38.5 \%$ for assault by youth relatives to $59.2 \%$ for social discrediting by peers). 
Exposure to family violence was also high, ranging from $35.3 \%$ for exposure to parental displaced aggression (such as punching walls) to $19.3 \%$ for exposure to severe physical assault of a parent. Caregiver-perpetrated victimizations were lower but still distressingly high, ranging from 9.9\% for food or medical neglect to $21.9 \%$ for psychological/emotional abuse by a caregiver. The mean number of victimizations reported was $6.45(S D=5.07)$ with a median of 6 . More than 8 in $10(86.3 \%)$ reported at least one lifetime victimization.

Table 1

Prevalence of Victimization Types

\begin{tabular}{|c|c|}
\hline Victimization type & Prevalence rate $(\%)$ \\
\hline Social discrediting by peers & 59.2 \\
\hline Witnessed assault without weapon & 58.4 \\
\hline Social exclusion by peers & 52.3 \\
\hline Assault by non-related peers & 50.4 \\
\hline Relational aggression by peers & 49.2 \\
\hline Witnessed assault with weapon & 48.4 \\
\hline Physical intimidation by peers & 44.8 \\
\hline Assault by youth relatives & 38.5 \\
\hline $\begin{array}{l}\text { Exposed to parental displaced } \\
\text { aggression }\end{array}$ & 35.3 \\
\hline $\begin{array}{l}\text { Exposed to parent pushed by } \\
\text { another parent }\end{array}$ & 28.2 \\
\hline Physical assault by adult & 24.8 \\
\hline Other family violence exposure & 21.9 \\
\hline Psychological/emotional abuse & 21.9 \\
\hline $\begin{array}{l}\text { Exposed to parent verbally } \\
\text { threatened }\end{array}$ & 21.2 \\
\hline Physical assault by caregiver & 20.0 \\
\hline $\begin{array}{l}\text { Exposed to parent severely } \\
\text { physically assaulted }\end{array}$ & 19.3 \\
\hline Neglect from parent incapacitation & 15.6 \\
\hline $\begin{array}{l}\text { Neglect from inappropriate adults } \\
\text { in the home }\end{array}$ & 12.4 \\
\hline Neglect from parental absence & 11.8 \\
\hline Neglect (food or medical) & 9.9 \\
\hline Any victimization & 86.3 \\
\hline Poly-victimization (sum) score & $\begin{array}{l}(M=6.45, S D=5.07, M d n=6 ; \\
\quad \text { range }=0-20)\end{array}$ \\
\hline
\end{tabular}

Note. $\quad N=2,565$.

Table 1. Prevalence of Victimization Types

\begin{tabular}{|l|c|}
\hline \multicolumn{1}{|c|}{ Victimization type } & Prevalence rate (\%) \\
\hline Social discrediting by peers & 59.2 \\
\hline Witnessed assault without weapon & 58.4 \\
\hline Social exclusion by peers & 52.3 \\
\hline Assault by non-related peers & 50.4 \\
\hline Relational aggression by peers & 49.2 \\
\hline Witnessed assault with weapon & 48.4 \\
\hline Physical intimidation by peers & 44.8 \\
\hline Assault by youth relatives & 38.5 \\
\hline Exposed to parental displaced aggression & 35.3 \\
\hline Exposed to parent pushed by another parent & 28.2 \\
\hline Physical assault by adult & 24.8 \\
\hline Other family violence exposure & 21.9 \\
\hline Psychological/emotional abuse & 21.9 \\
\hline
\end{tabular}




\begin{tabular}{|l|c|}
\hline Exposed to parent verbally threatened & 21.2 \\
\hline Physical assault by caregiver & 20.0 \\
\hline Exposed to parent severely physically assaulted & 19.3 \\
\hline Neglect from parent incapacitation & 15.6 \\
\hline Neglect from inappropriate adults in the home & 12.4 \\
\hline Neglect from parental absence & 11.8 \\
\hline Neglect (food or medical) & 9.9 \\
\hline Any victimization & 86.3 \\
\hline Poly-victimization (sum) score & $(M=6.45, S D=5.07, M d n=6 ;$ \\
\hline & range $=0-20)$ \\
\hline Note. $N=2,565$. & \\
\hline
\end{tabular}

Other adverse life events

Other stressful events were also commonly reported. These other adversities represent experiences that were not intentionally perpetrated, such as natural disasters and unemployment. See Table 2. Two of these, the death or hospitalization of a friend or family member, were reported by a majority of respondents. Most were reported by approximately one fifth to one third of the sample, with parental unemployment and high parental conflict being the most common after death and hospitalization. Parent military deployment was the least frequent stressful life event, reported by $12.6 \%$ of the sample. Overall, 9 in 10 participants (90.6\%) reported at least one adverse life event.

Table 2

Prevalence of Adverse Life Events

\begin{tabular}{lc}
\hline \multicolumn{1}{c}{ Adverse event } & Prevalence rate $(\%)$ \\
\hline Friend or family death & 72.9 \\
Friend or family hospitalization & 65.7 \\
Parent unemployment & 36.5 \\
Parent conflict & 35.2 \\
Hospitalization & 30.9 \\
Family substance abuse & 30.7 \\
Friend or family suicide attempt & 25.4 \\
Home damaged in disaster & 21.9 \\
Parent incarceration & 21.7 \\
Repeat school year & 19.1 \\
Parent military deployment & 12.6 \\
Any adverse life event & 90.6 \\
Life event sum score & $(M=3.72, S D=2.44, M d n=3 ;$ \\
& range $=0-11)$ \\
\hline
\end{tabular}

Note. $\quad N=2,565$.

Table 2. Prevalence of Adverse Life Events

\begin{tabular}{|l|c|}
\hline \multicolumn{1}{|c|}{ Adverse event } & Prevalence rate (\%) \\
\hline Friend or family death & 72.9 \\
\hline Friend or family hospitalization & 65.7 \\
\hline Parent unemployment & 36.5 \\
\hline Parent conflict & 35.2 \\
\hline Hospitalization & 30.9 \\
\hline Family substance abuse & 30.7 \\
\hline
\end{tabular}




\begin{tabular}{|l|c|}
\hline Friend or family suicide attempt & 25.4 \\
\hline Home damaged in disaster & 21.9 \\
\hline Parent incarceration & 21.7 \\
\hline Repeat school year & 19.1 \\
\hline Parent military deployment & 12.6 \\
\hline Any adverse life event & 90.6 \\
\hline Life event sum score & $(M=3.72, S D=2.44, M d n=3 ;$ range $=0-11)$ \\
\hline Note. $N=2,565$. & \\
\hline
\end{tabular}

\section{Financial strain}

Financial strain was also common (see Table 3). One indicator of financial strain was reported by more than half the sample, difficulty covering unexpected expenses in excess of $\$ 500$. Between one third and one half reported challenges meeting other regular expenses. The least common reported form of strain was being behind one month or more on rent or mortgage payments, but troublingly that still indicates that one in six participants were potentially vulnerable to eviction. Almost three in four $(70.7 \%)$ reported some experience of financial strain.

Table 3

Prevalence of Financial Strain

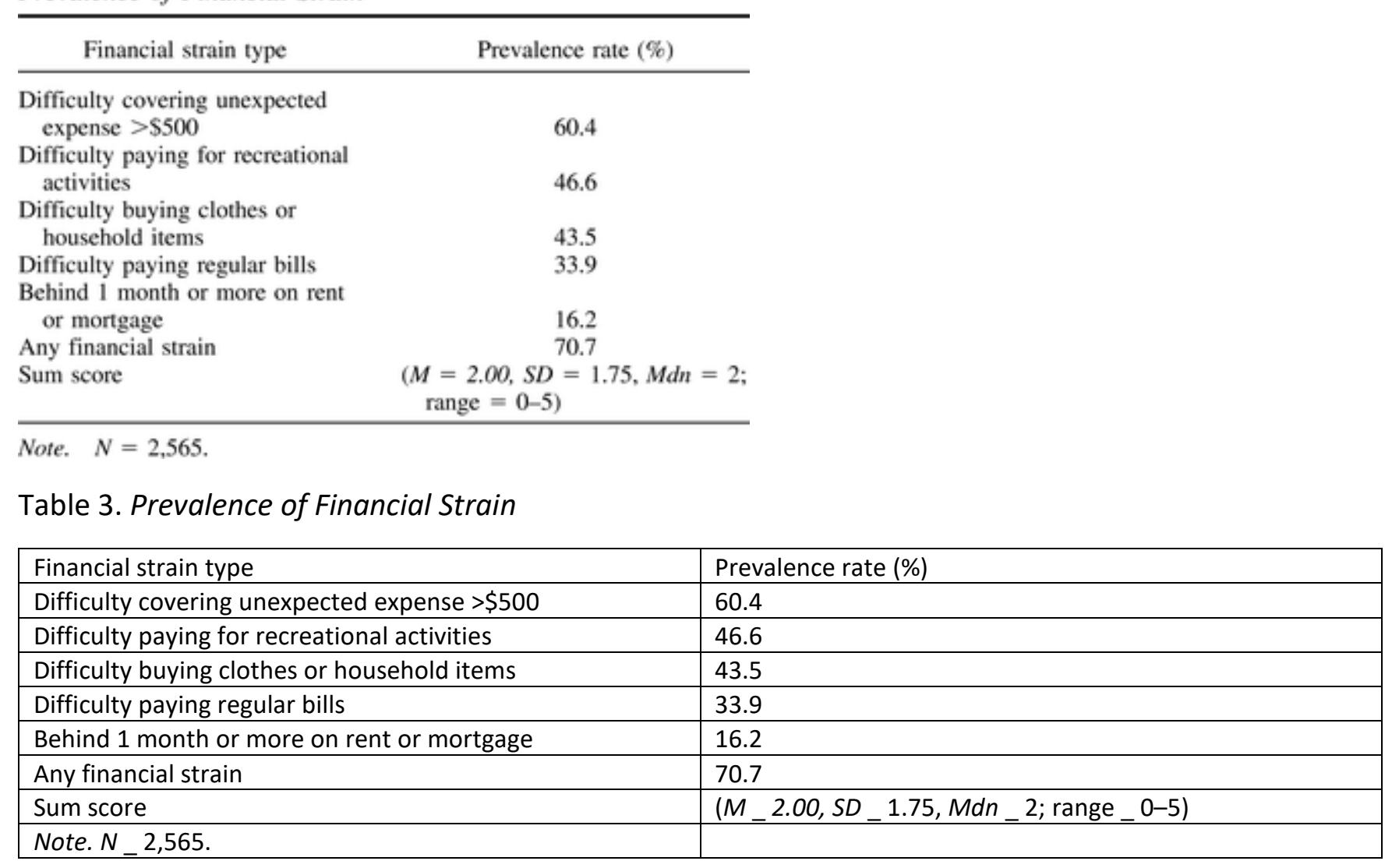

Altogether, as seen in Table 4, almost everyone in the sample reported at least one type of adversity (98.5\%), suggesting that experiences of adversity are a nearly unavoidable aspect of life. More 
disturbingly, more than half of the sample endorsed at least one adverse experience in all three domains, interpersonal victimization, life events, and financial strain.

Table 4

Total Number of Adversity Types Experienced (Victimization,

Life Events, and/or Financial Strain)

\begin{tabular}{cc}
\hline Number of adversity types & $\%$ of sample \\
\hline 0 & 1.5 \\
1 & 8.4 \\
2 & 31.5 \\
3 & 58.6 \\
\hline
\end{tabular}

Table 4. Total Number of Adversity Types Experienced (Victimization, Life Events, and/or Financial Strain)

\begin{tabular}{|c|c|}
\hline $\begin{array}{c}\text { Number of } \\
\text { adversity types }\end{array}$ & $\begin{array}{c}\% \text { of } \\
\text { sample }\end{array}$ \\
\hline 0 & 1.5 \\
\hline 1 & 8.4 \\
\hline 2 & 31.5 \\
\hline 3 & 58.6 \\
\hline
\end{tabular}

\section{Thriving}

Despite the substantial burden of adversity in this sample and significant bivariate associations indicating reduced well-being and mental health for participants reporting greater adversity (see bivariate correlations for all variables in Table 5), many people reported high levels of well-being. More than half the sample stated that every item on the subjective well-being and posttraumatic growth scales were "somewhat true about me" or "mostly true about me." To give a few specific examples, $\mathbf{7 7 . 0 \%}$ of participants reported that "I am satisfied with my life" and $87.5 \%$ endorsed that "I have a lot to be proud of" (both from the subjective well-being index). Regarding posttraumatic growth, typical findings include the $84.3 \%$ who reported that "I discovered that I am stronger than I thought I was" and $69.3 \%$ who endorsed "I changed my priorities about what is important in life." Although substantial numbers of participants reported some mental health symptoms, most symptoms were endorsed by less than half the sample (range $23.6 \%$ to $57.7 \%$ ). The most commonly reported symptom was "Worrying about things in the last month," described as somewhat or mostly true by $57.7 \%$ of the sample (the only symptom reported by more than half of the sample). 
Table 5

Bivariate Correlations Among Study Variables

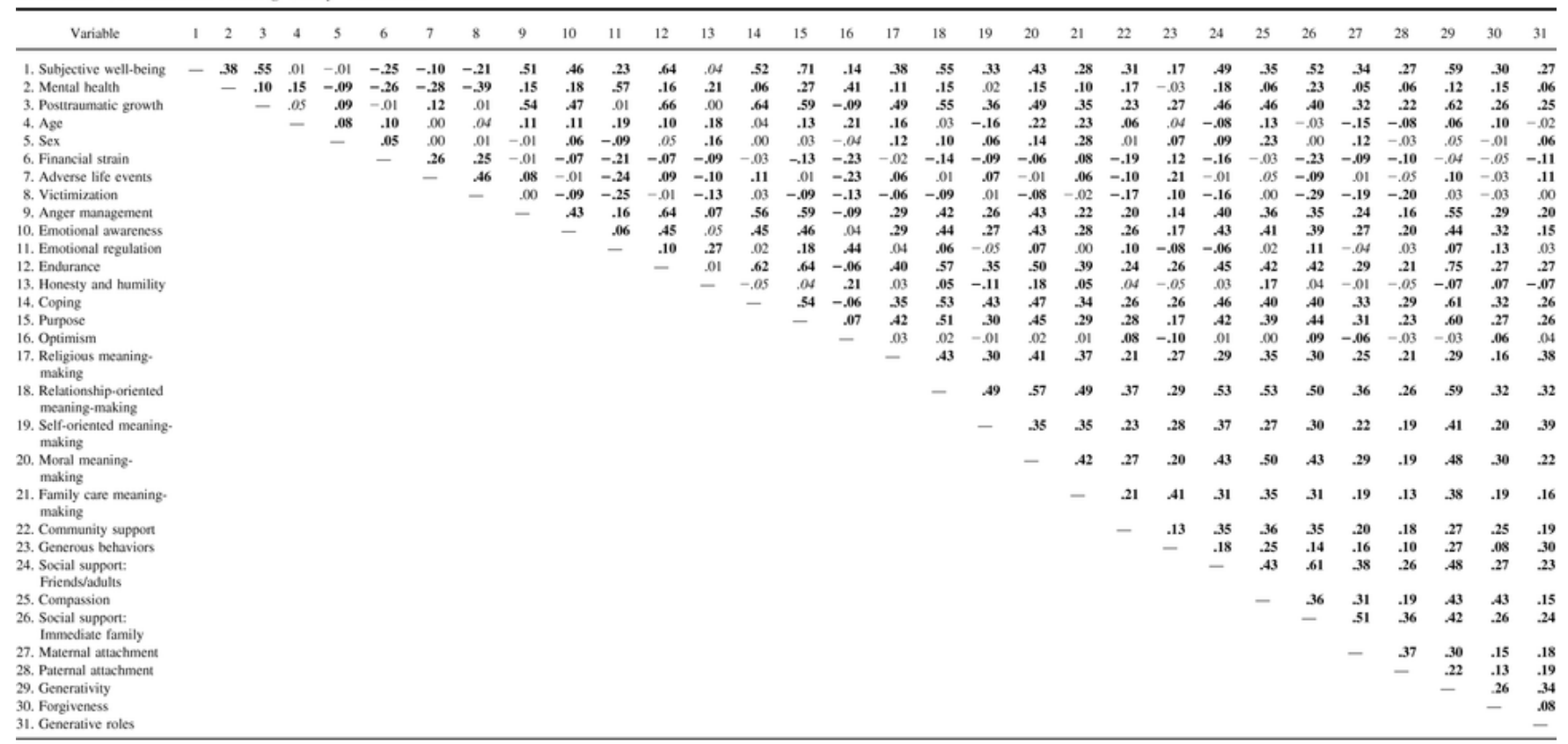

Note. Italics indicate significance at .05 level. Bold indicates significance at .01 level. The sex variable was dichotomous, with a higher value corresponding to "female."

Table 5. Bivariate Correlations Among Study Variables

\begin{tabular}{|c|c|c|c|c|c|c|c|c|c|c|c|c|c|c|c|c|c|c|c|c|c|c|c|c|c|c|c|c|c|c|}
\hline $\begin{array}{l}\text { Var } \\
\text { iabl } \\
\text { e }\end{array}$ & 1 & 2 & 3 & 4 & 5 & 6 & 7 & 8 & & $\begin{array}{l}9 \\
0\end{array}$ & $\begin{array}{l}1 \\
1\end{array}$ & $\frac{1}{2}$ & $\frac{1}{3}$ & $\frac{1}{4}$ & & $\frac{1}{6}$ & $\frac{1}{7}$ & $\frac{1}{8}$ & $\frac{1}{9}$ & ${ }_{0}^{2}$ & $\underset{1}{2}$ & $\frac{2}{2}$ & $\frac{2}{3}$ & $\begin{array}{l}2 \\
4\end{array}$ & ${ }_{6}^{2}$ & & $\begin{array}{l}2 \\
8\end{array}$ & $\begin{array}{l}2 \\
\mathbf{g}\end{array}$ & & $\begin{array}{l}3 \\
1\end{array}$ \\
\hline $\begin{array}{l}1 . \\
\text { Sub } \\
\text { ject } \\
\text { ive } \\
\text { wel } \\
\text { wel } \\
\text { bei } \\
\text { ng }\end{array}$ & - & $\begin{array}{l}\dot{3} \\
8\end{array}$ & $\begin{array}{l}\dot{5} \\
5\end{array}$ & $\begin{array}{l}\dot{0} \\
1\end{array}$ & $\begin{array}{l}- \\
\dot{0} \\
1\end{array}$ & $\begin{array}{l}- \\
\dot{2} \\
5\end{array}$ & $\begin{array}{l}- \\
\dot{1} \\
0\end{array}$ & $\dot{2}$ & & $\begin{array}{l}\dot{5} \\
1 \\
1\end{array}$ & $\dot{2}$ & $\begin{array}{l}\dot{6} \\
4\end{array}$ & ${ }_{4}^{\circ}$ & $\dot{5}$ & & $\frac{1}{4}$ & $\begin{array}{l}\dot{3} \\
\dot{8}\end{array}$ & $\dot{5}$ & $\begin{array}{l}\dot{3} \\
3\end{array}$ & $\dot{4}_{3}$ & $\dot{2}$ & $\begin{array}{l}\dot{3} \\
1\end{array}$ & $\frac{\dot{1}}{7}$ & $\begin{array}{l}\dot{a} \dot{3} \\
g\end{array}$ & $\begin{array}{l}\dot{5} \\
2\end{array}$ & & $\frac{2}{7}$ & $\begin{array}{l}\dot{5} \\
\mathbf{g}\end{array}$ & & $\dot{2}$ \\
\hline $\begin{array}{l}2 . \\
\text { Me } \\
\text { nta } \\
\text { hea } \\
\text { lth }\end{array}$ & & & $\dot{1}$ & $\dot{1}$ & $\begin{array}{l}- \\
\dot{0} \\
9\end{array}$ & $\bar{i}$ & $\begin{array}{l}\overline{2} \\
\dot{8}\end{array}$ & $\begin{array}{l}\dot{3} \\
\mathrm{~g}\end{array}$ & & $\begin{array}{l}1 \\
5 \\
5\end{array}$ & $\dot{5}$ & $\dot{i}_{6}$ & $\dot{2}$ & $\dot{0}$ & & $\begin{array}{l}4 \\
1\end{array}$ & $\begin{array}{l}\dot{1} \\
\dot{1}\end{array}$ & $\stackrel{i}{5}$ & $\begin{array}{l}\dot{0} \\
2\end{array}$ & $\frac{1}{5}$ & $\dot{i}$ & $\frac{1}{7}$ & $\begin{array}{l}\dot{0} \\
\dot{0}\end{array}$ & $\frac{1}{8}$ & $\dot{2}$ & & $\begin{array}{l}0 \\
6\end{array}$ & $\frac{\dot{1}}{2}$ & & $\begin{array}{l}\dot{0} \\
6\end{array}$ \\
\hline $\begin{array}{l}3 . \\
\text { Pos } \\
\text { tra } \\
\text { um } \\
\text { atic } \\
\text { gro } \\
\text { wt } \\
\text { ht }\end{array}$ & & & & $\begin{array}{l}0 \\
0 \\
5\end{array}$ & $\begin{array}{l}\dot{0} \\
9\end{array}$ & $\begin{array}{l}- \\
\dot{0} \\
1\end{array}$ & $\dot{\mathbf{i}}$ & $\begin{array}{l}\dot{C} \\
1\end{array}$ & & $\begin{array}{l}54 \\
4\end{array}$ & $\begin{array}{l}\dot{0} \\
1\end{array}$ & $\begin{array}{l}\dot{6} \\
6\end{array}$ & $\begin{array}{l}\dot{C} \\
\dot{c}\end{array}$ & $\begin{array}{l}\dot{6} \\
4\end{array}$ & $\begin{array}{l}\dot{5} \\
9\end{array}$ & $\dot{-}$ & $\dot{\vec{A}}$ & $\dot{5}$ & $\begin{array}{l}\dot{3} \\
6\end{array}$ & $\dot{4}$ & $\begin{array}{l}\dot{3} \\
5\end{array}$ & $\dot{2}$ & $\dot{2}$ & $\begin{array}{l}\dot{A} \dot{G} \\
\dot{G}\end{array}$ & $\begin{array}{l}\dot{A} \\
0\end{array}$ & & $\frac{2}{2}$ & $\begin{array}{l}\dot{6} \\
2\end{array}$ & & $\dot{2}$ \\
\hline $\begin{array}{l}4 . \\
\mathrm{Ag} \\
\mathrm{e}\end{array}$ & & & & - & $\dot{0}$ & $\dot{i}$ & $\dot{c}$ & c & & $\begin{array}{l}1 \\
1 \\
1\end{array}$ & $\dot{i}$ & $\stackrel{i}{0}$ & $\stackrel{\dot{1}}{8}$ & $\begin{array}{l}0 \\
4\end{array}$ & & 1 & $\begin{array}{l}\dot{1} \\
6\end{array}$ & $\begin{array}{l}0 \\
3\end{array}$ & $\frac{i}{6}$ & $\dot{2}$ & $\dot{2}$ & $\begin{array}{l}0 \\
6\end{array}$ & $\begin{array}{l}0 \\
4\end{array}$ & $\dot{1}$ & $\begin{array}{l}- \\
\dot{0} \\
3\end{array}$ & $\begin{array}{l}- \\
\frac{1}{5}\end{array}$ & $\begin{array}{l}- \\
\dot{0}\end{array}$ & $\frac{\dot{0}}{6}$ & & \\
\hline $\begin{array}{l}5 . \\
\text { Sex }\end{array}$ & & & & & & $\begin{array}{l}\dot{0} \\
5\end{array}$ & $\dot{d}$ & $\begin{array}{l}0 \\
1\end{array}$ & & $\begin{array}{l}0 \\
0 \\
0\end{array}$ & $\dot{0}$ & $\begin{array}{l}\dot{C} \\
5\end{array}$ & $\underset{6}{j}$ & $\dot{0}$ & $\begin{array}{l}0 \\
3\end{array}$ & $\overline{0}$ & $\frac{i}{2}$ & $\stackrel{i}{0}$ & $\begin{array}{l}\dot{0} \\
6\end{array}$ & $\dot{i}$ & $\dot{2}_{8}$ & $\begin{array}{l}\dot{0} \\
1\end{array}$ & $\dot{0} 7$ & $\begin{array}{l}\dot{0} \\
\dot{g}\end{array}$ & $\begin{array}{l}\dot{d} \\
\dot{c}\end{array}$ & $\frac{\dot{1}}{2}$ & $\begin{array}{l}- \\
\dot{0}\end{array}$ & $\begin{array}{l}0 \\
0 \\
5\end{array}$ & 0 & $\begin{array}{l}\dot{0} \\
6\end{array}$ \\
\hline $\begin{array}{l}6.6 \\
\text { fin } \\
\text { fanc } \\
\text { ial } \\
\text { str } \\
\text { ain } \\
7\end{array}$ & & & & & & - & & $\begin{array}{l}\dot{2} \\
5\end{array}$ & $\begin{array}{l}- \\
0 \\
1\end{array}$ & $\begin{array}{l}- \\
0 \\
7\end{array}$ & $\begin{array}{l}- \\
\dot{2} \\
1\end{array}$ & $\begin{array}{l}- \\
\dot{0}\end{array}$ & $\begin{array}{l}- \\
\dot{0} \\
9\end{array}$ & $\begin{array}{l}- \\
\dot{0} \\
3\end{array}$ & $\frac{\dot{1}}{3}$ & $\frac{1}{3}$ & $\begin{array}{l}- \\
\dot{0} \\
2\end{array}$ & $\frac{i}{4}$ & $\begin{array}{l}\dot{0} \\
9\end{array}$ & $\overline{0}$ & $\begin{array}{l}\dot{0} \\
8\end{array}$ & $\begin{array}{l}\bar{i} \\
\overline{9}\end{array}$ & $\frac{\dot{1}}{2}$ & $\begin{array}{cc}- & 7 \\
\dot{1} & \dot{c}\end{array}$ & $\begin{array}{l}- \\
\dot{2}\end{array}$ & $\begin{array}{l}- \\
\dot{0} \\
9\end{array}$ & $\begin{array}{l}- \\
\dot{1} \\
0\end{array}$ & $\begin{array}{l}- \\
0 \\
4\end{array}$ & $\begin{array}{l}1 \\
0 \\
5\end{array}$ & \\
\hline $\begin{array}{l}7 . \\
\text { Ad } \\
\text { ver } \\
\text { see } \\
\text { life } \\
\text { eve } \\
\text { nts }\end{array}$ & & & & & & & & & $\begin{array}{l}0 \\
6\end{array}$ & $\begin{array}{l}- \\
0 \\
1\end{array}$ & & $\begin{array}{l}\dot{0} \\
9\end{array}$ & $\stackrel{i}{0}$ & $\dot{1}$ & $\begin{array}{l}\dot{0} \\
1\end{array}$ & $\dot{2}$ & $\dot{0}$ & $\begin{array}{l}\dot{c} \\
1\end{array}$ & $\dot{0}$ & & $\begin{array}{l}\dot{0} \\
6\end{array}$ & $\begin{array}{l}- \\
\dot{1} \\
0\end{array}$ & $\dot{2}$ & $\begin{array}{l}0 \\
0\end{array}$ & $\dot{g}$ & $\begin{array}{l}\dot{0} \\
1\end{array}$ & $\begin{array}{l}- \\
0 \\
5\end{array}$ & $\begin{array}{l}\dot{1} \\
0\end{array}$ & $\begin{array}{l}0 \\
0 \\
B\end{array}$ & $\frac{\dot{1}}{1}$ \\
\hline $\begin{array}{l}\text { 8. } \\
\text { Vic } \\
\text { tim } \\
\text { izat } \\
\text { ion }\end{array}$ & & & & & & & & & $\begin{array}{l}0 \\
0\end{array}$ & $\begin{array}{l}- \\
\dot{0} \\
9\end{array}$ & $\begin{array}{l}- \\
\dot{2} \\
5\end{array}$ & $\begin{array}{l}- \\
0 \\
1\end{array}$ & $\frac{1}{3}$ & $\begin{array}{l}0 \\
3\end{array}$ & $\begin{array}{l}\dot{0} \\
9\end{array}$ & $\frac{1}{3}$ & $\begin{array}{l}- \\
\dot{0} \\
6\end{array}$ & $\dot{g}$ & 1 & $\dot{0}$ & $\begin{array}{l}- \\
\dot{0} \\
2\end{array}$ & $\begin{array}{l}- \\
\dot{1}\end{array}$ & $\dot{1}$ & $i_{6}$ & $\begin{array}{l}- \\
\dot{2}\end{array}$ & $\begin{array}{l}- \\
\dot{i}\end{array}$ & $\begin{array}{l}- \\
\dot{2}\end{array}$ & $\begin{array}{l}\dot{0} \\
3\end{array}$ & & $\begin{array}{l}\dot{0} \\
0\end{array}$ \\
\hline $\begin{array}{l}9 . \\
\text { An } \\
\text { ger } \\
\text { ma } \\
\text { nag }\end{array}$ & & & & & & & & & & $\begin{array}{l}4 \\
3\end{array}$ & $\stackrel{i}{6}$ & $\begin{array}{l}\dot{6} \\
4\end{array}$ & $\dot{0}$ & $\begin{array}{l}\dot{5} \\
6\end{array}$ & $\dot{5}$ & $\dot{0}$ & $\dot{\mathbf{2}}$ & $\begin{array}{l}\dot{4} \\
2\end{array}$ & $\dot{2}$ & $\begin{array}{l}\dot{4} \\
3\end{array}$ & & $\begin{array}{l}2 \\
0\end{array}$ & $\dot{i}_{4}$ & $\dot{a} \dot{3}$ & $\begin{array}{l}\dot{3} \\
5\end{array}$ & & $\frac{1}{6}$ & $\begin{array}{l}\dot{5} \\
5\end{array}$ & & $\dot{2}$ \\
\hline
\end{tabular}




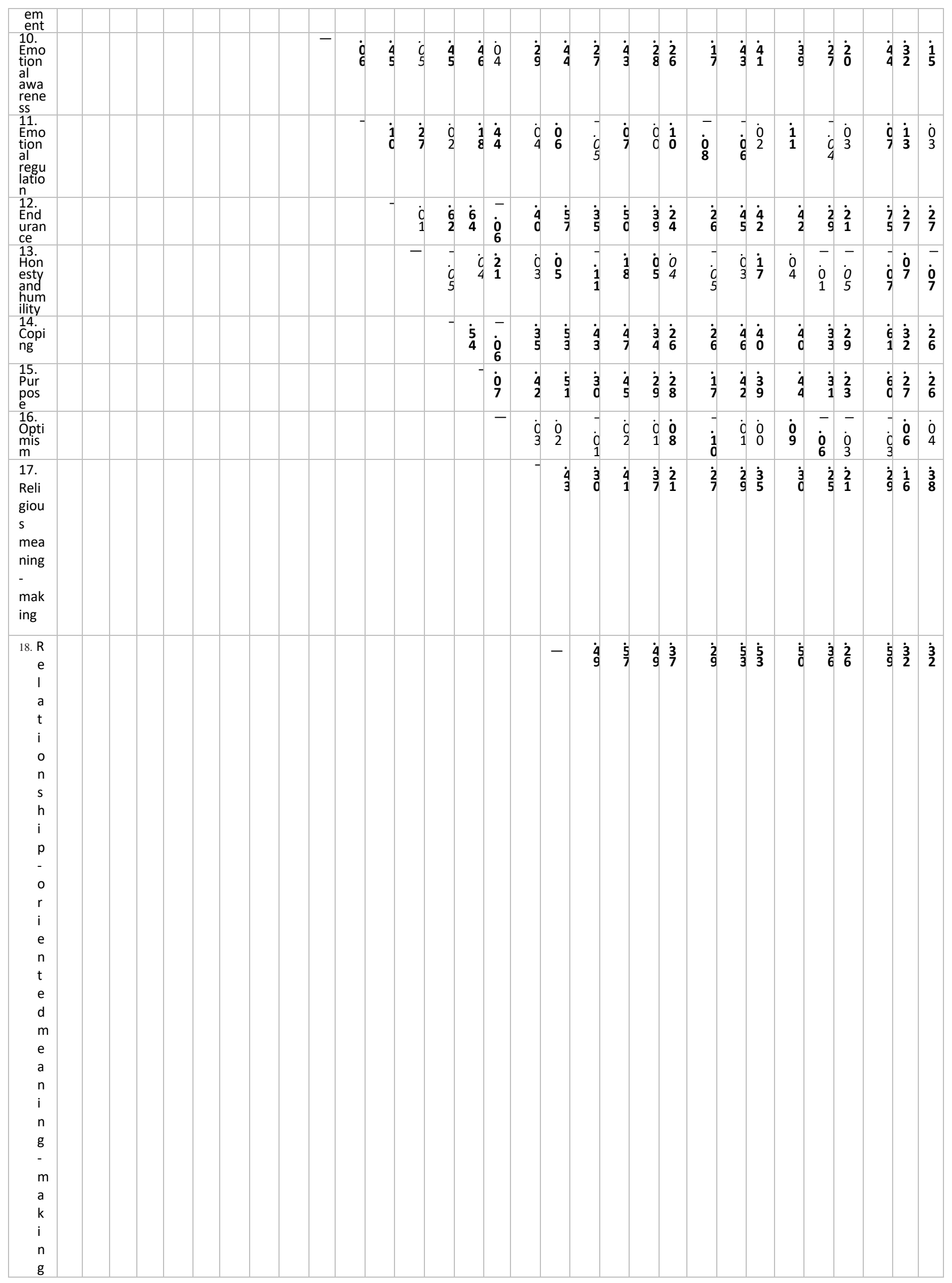




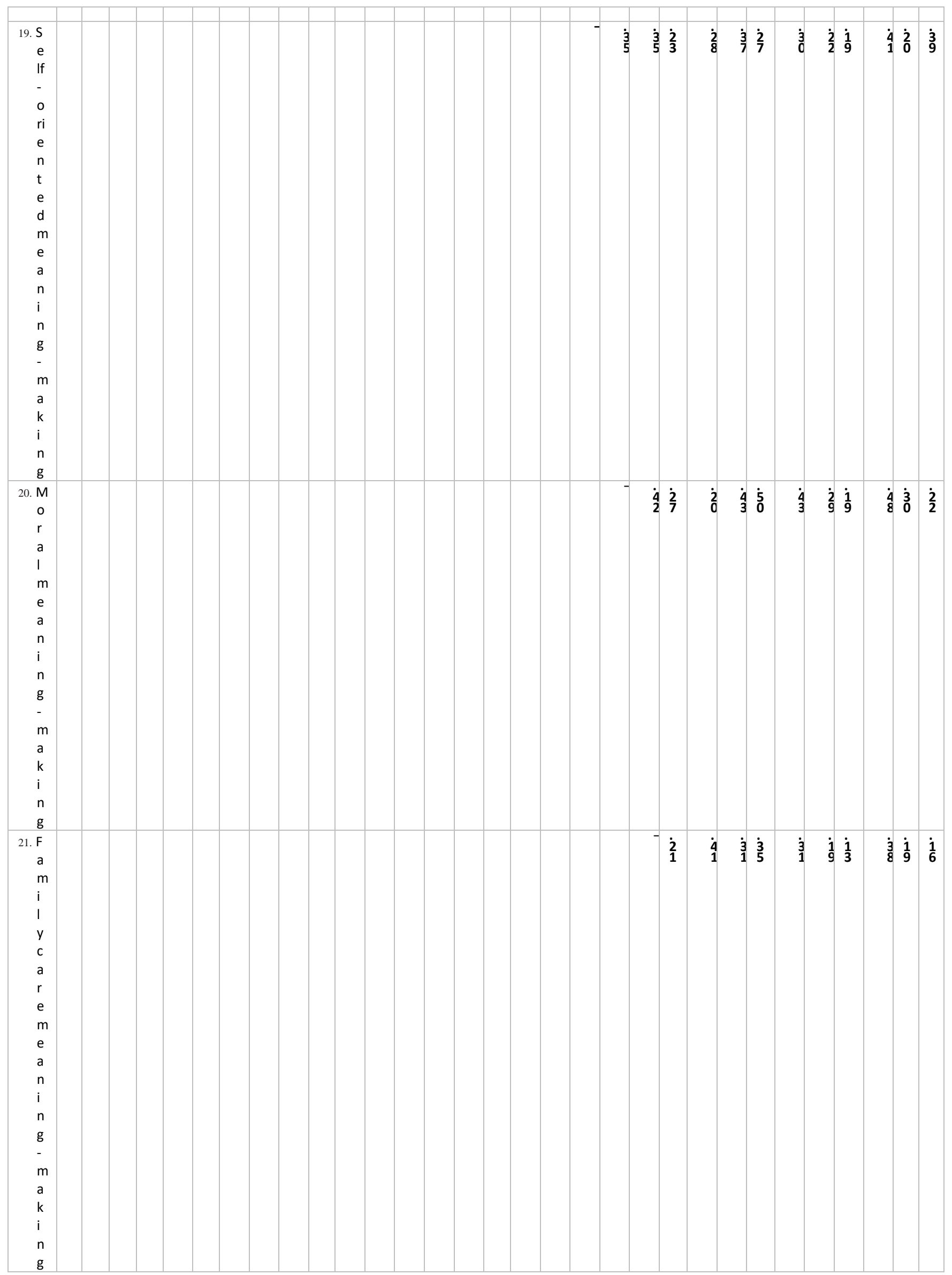




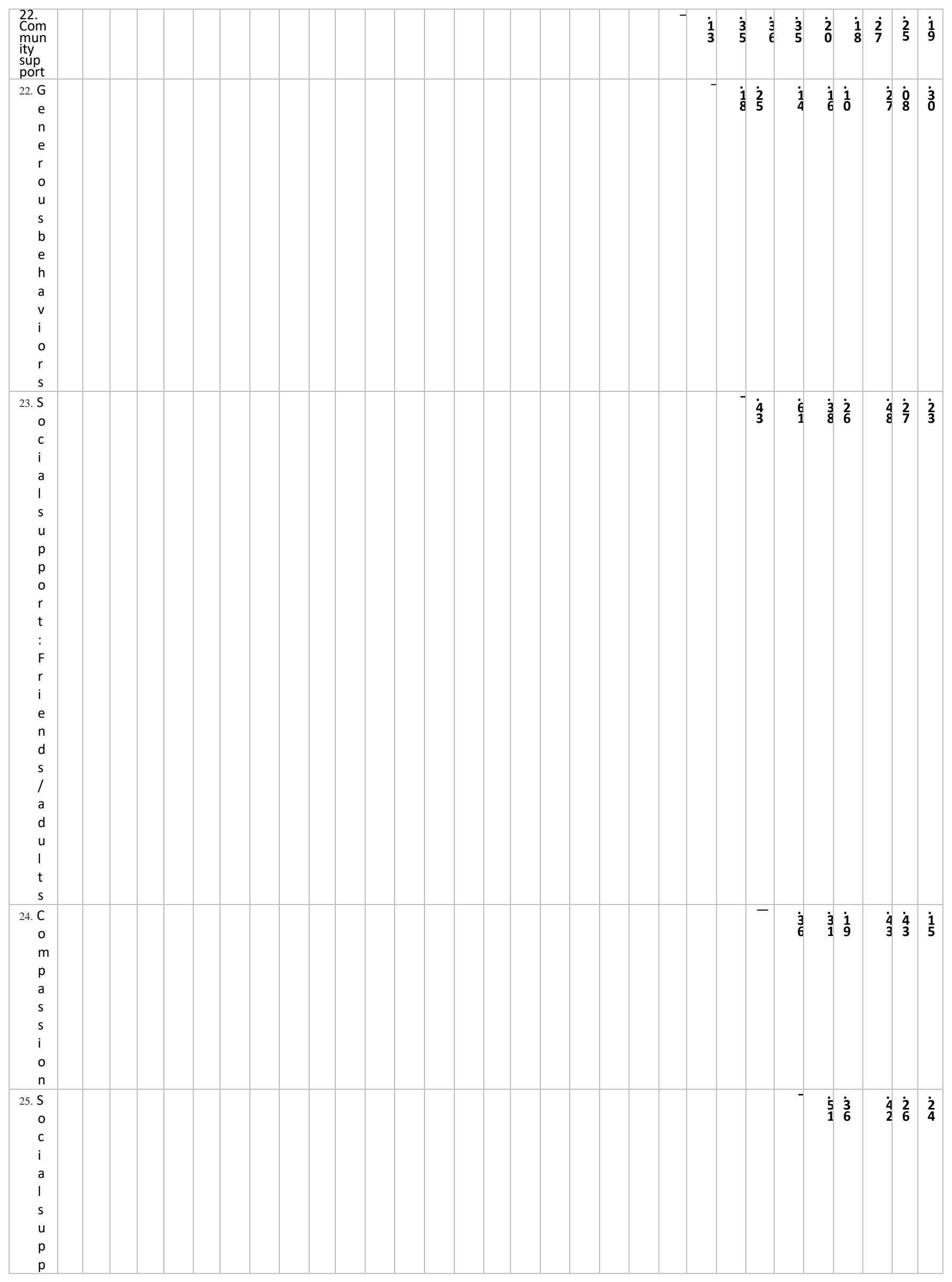




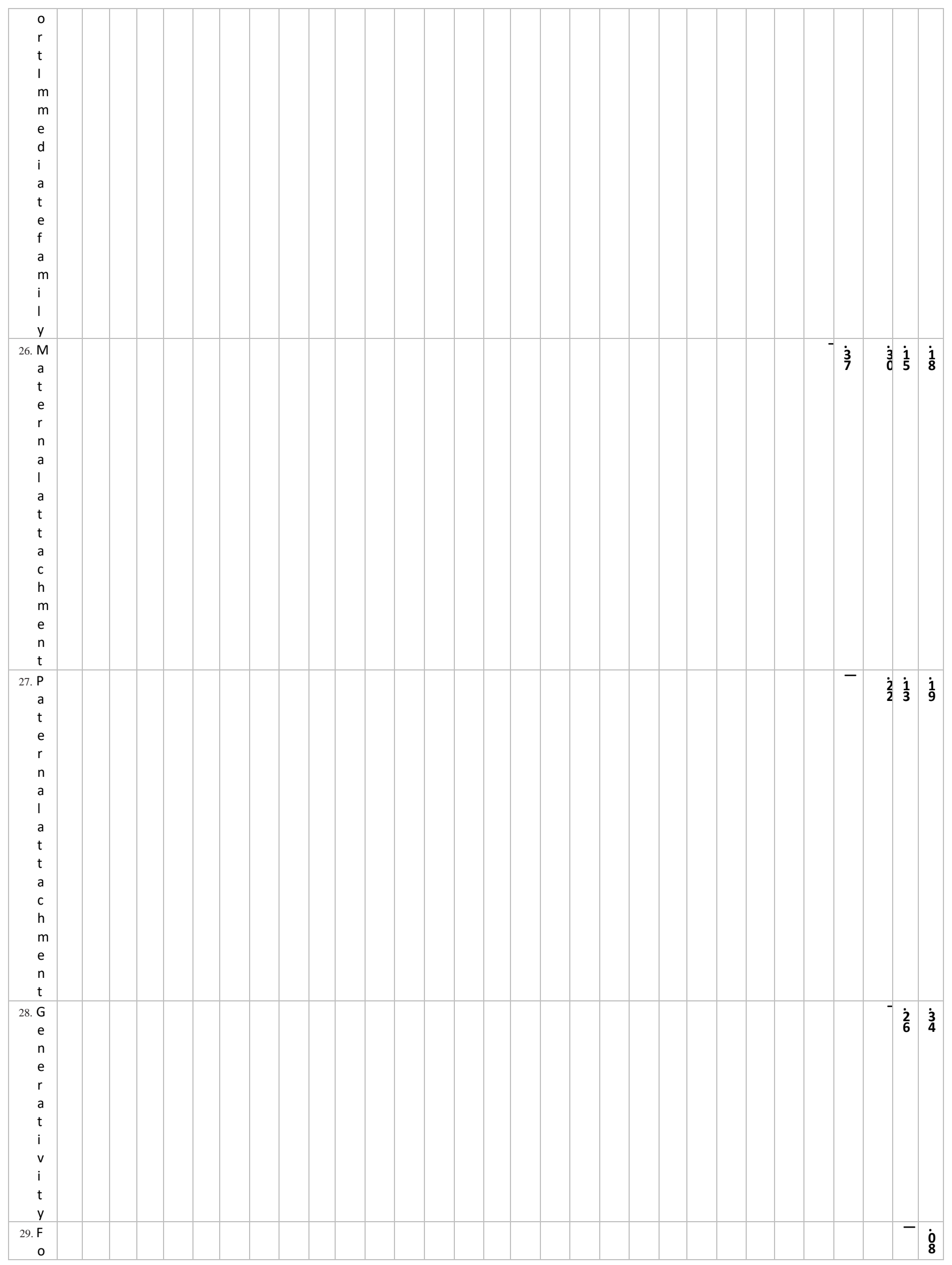




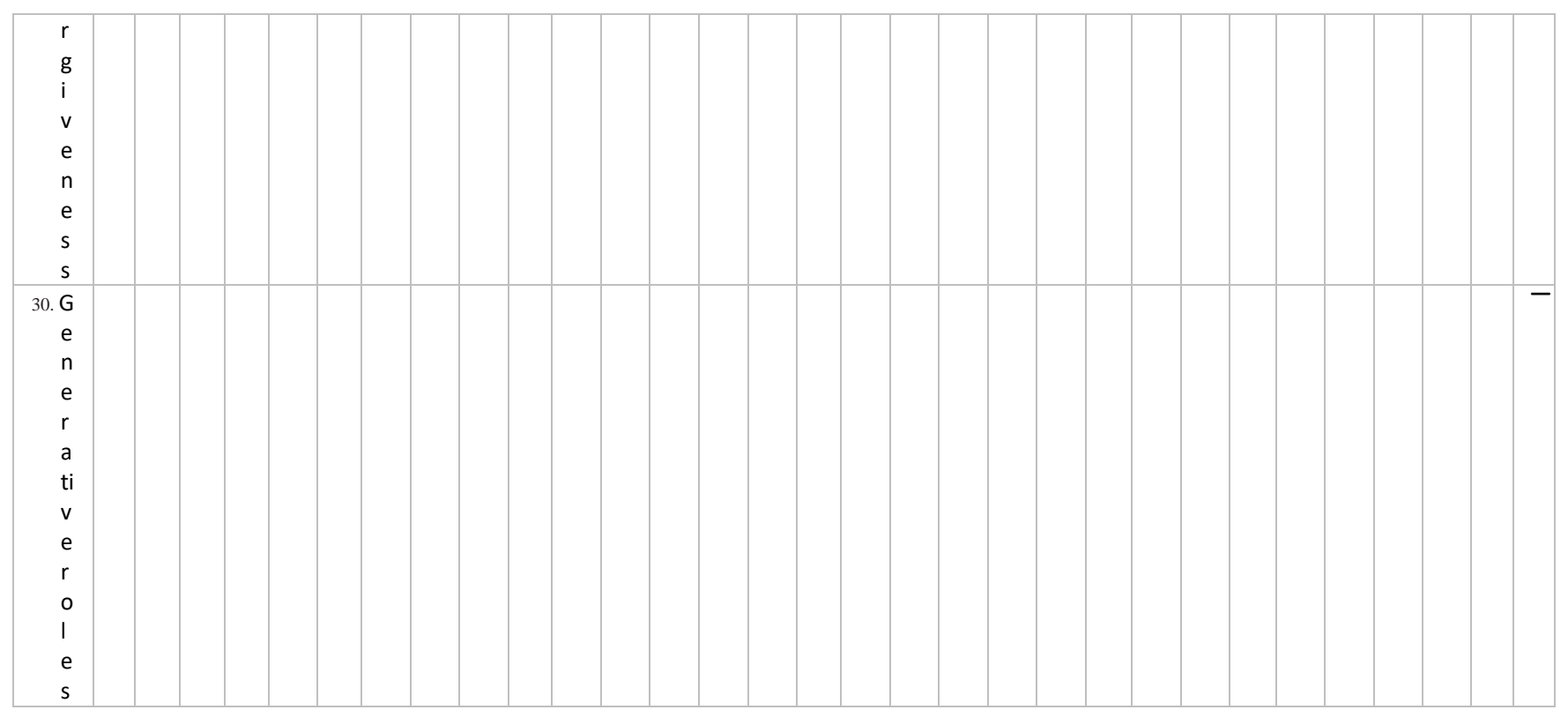

\section{Factors Associated With Thriving}

We conducted hierarchical logistic regression analyses to identify which, if any, protective factors were associated with thriving after considering individuals' adversity burdens. To focus on factors that were associated with above average functioning, we defined "thriving" as scores that were at least 0.5 standard deviation above the mean for each outcome measure, subjective well-being, posttraumatic growth, and mental health (in the latter case, thriving was defined as fewer symptoms). In each logistic regression, age and sex were entered in the first block, adversities in the second block, and polystrengths and individual resilience portfolio (protective) factors in the third block (see Table 6 for complete list of variables in equations). 
Table 6

Logistic Regressions Predicting Outcomes From Strengths and Adversities

\begin{tabular}{|c|c|c|c|c|c|c|}
\hline & \multicolumn{2}{|c|}{ Subjective well-being } & \multicolumn{2}{|c|}{ Posttraumatic growth } & \multicolumn{2}{|c|}{ Mental health } \\
\hline & Odds ratio & $95 \% \mathrm{CI}$ & Odds ratio & $95 \% \mathrm{CI}$ & Odds ratio & $95 \% \mathrm{CI}$ \\
\hline & \multicolumn{6}{|c|}{ Demographics } \\
\hline Age & $.97^{* * *}$ & $.96-.98$ & $.99^{\circ}$ & $.98-1.00$ & 1.01 & $1.00-1.02$ \\
\hline Sex & .92 & $.68-1.24$ & 1.01 & $.76-1.36$ & $.77^{\dagger}$ & $.58-1.00$ \\
\hline \multirow[t]{2}{*}{$R^{2}$ demographics only } & .00 & & .01 & & .04 & \\
\hline & \multicolumn{6}{|c|}{ Adversities } \\
\hline Financial strain & $.87^{\cdots *}$ & $.83-.92$ & $1.11^{* \cdots}$ & $1.06-1.17$ & $.94^{\circ}$ & $.90-.99$ \\
\hline Poly-victimization & .97 & $.94-1.01$ & 1.00 & $.97-1.03$ & $90^{* * *}$ & $.87-.93$ \\
\hline & $.91^{\circ}$ & $.85-.97$ & 1.05 & $.99-1.12$ & .98 & $.92-1.04$ \\
\hline \multirow{2}{*}{$\Delta R^{2}$ adversities added } & .10 & & .00 & & .15 & \\
\hline & \multicolumn{6}{|c|}{ Resilience portfolio strengths } \\
\hline \multirow[t]{2}{*}{ Poly-strengths } & $1.26^{* * *}$ & $1.18-1.35$ & $1.15^{* * *}$ & $1.08-1.23$ & $1.06^{\circ}$ & $1.01-1.12$ \\
\hline & \multicolumn{6}{|c|}{ Regulatory strengths } \\
\hline Endurance & $1.47^{* *}$ & $1.13-1.92$ & $1.79^{* *}$ & $1.38-2.31$ & 1.20 & $.96-1.51$ \\
\hline Emotional Awareness & 1.14 & $.92-1.41$ & $1.38^{* *}$ & $1.12-1.70$ & $1.30^{* *}$ & $1.10-1.54$ \\
\hline Emotional Regulation & .89 & $.75-1.05$ & $.83^{\circ}$ & $.71-.97$ & $2.47^{* * *}$ & $2.10-2.90$ \\
\hline Coping & 1.03 & $.85-1.27$ & $1.54^{* * *}$ & $1.26-1.88$ & .87 & $.72-1.04$ \\
\hline Honesty and Humility & 1.12 & $.96-1.31$ & .95 & $.82-1.11$ & 1.10 & $.94-1.28$ \\
\hline \multirow[t]{2}{*}{ Anger Management } & 1.05 & $.85-1.29$ & .90 & $.74-1.11$ & .91 & $.76-1.10$ \\
\hline & \multicolumn{6}{|c|}{ Meaning-making strengths } \\
\hline Purpose & $2.16^{* * *}$ & $1.74-2.67$ & $1.65^{*+*}$ & $1.35-2.02$ & $1.25^{*}$ & $1.04-1.50$ \\
\hline Optimism & $1.19^{*}$ & $1.01-1.39$ & .86 & $.74-1.01$ & $1.27^{* *}$ & $1.10-1.47$ \\
\hline Religious meaning-making & 1.06 & $.90-1.24$ & $1.55^{* * *}$ & $1.33-1.80$ & .95 & $.82-1.09$ \\
\hline Self-oriented meaning making & .89 & $.75-1.06$ & 1.11 & $.94-1.30$ & 1.00 & $.86-1.17$ \\
\hline Relationship-oriented meaning-making & 1.17 & $.92-1.48$ & .96 & $.77-1.20$ & .91 & $.75-1.12$ \\
\hline Moral meaning-making & $.80^{\circ}$ & $.65-.97$ & 1.01 & $.82-1.23$ & .98 & $.82-1.16$ \\
\hline \multirow[t]{2}{*}{ Family care meaning-making } & $.71^{* * *}$ & $.59-.85$ & .84 & $.71-1.00$ & 1.10 & $.93-1.29$ \\
\hline & \multicolumn{6}{|c|}{ Interpersonal strengths } \\
\hline Generativity & $1.54^{* * *}$ & $1.21-1.96$ & 1.15 & $.92-1.45$ & .93 & $.75-1.15$ \\
\hline Compassion & .90 & $.72-1.13$ & $1.49^{* *}$ & $1.18-1.89$ & .96 & $.80-1.15$ \\
\hline Social support: Immediate family & 1.10 & $.90-1.35$ & 1.04 & $.86-1.26$ & 1.08 & $.90-1.30$ \\
\hline Social support: Friends/adults & 1.03 & $.84-1.28$ & .94 & $.77-1.16$ & 1.16 & $.97-1.39$ \\
\hline Community support & 1.11 & $.95-1.31$ & .93 & $.81-1.09$ & 1.01 & $.88-1.17$ \\
\hline Forgiveness & 1.11 & $.94-1.31$ & .90 & $.77-1.05$ & 1.03 & $.90-1.19$ \\
\hline Generous behaviors & 1.05 & $.90-1.23$ & .92 & $.80-1.07$ & 1.04 & $.90-1.19$ \\
\hline Generative roles & .90 & $.77-1.06$ & .86 & $.74-1.00$ & .89 & $.77-1.04$ \\
\hline Maternal attachment & .92 & $.78-1.08$ & .93 & $.79-1.08$ & $.82^{*}$ & $.70-.96$ \\
\hline Paternal attachment & .87 & $.75-1.01$ & $.86^{\circ}$ & $.75-.98$ & .95 & $.83-1.08$ \\
\hline$\Delta R^{2}$ resilience portfolio strengths added & .48 & & .49 & & .23 & \\
\hline Final $R^{2}$ full model & .58 & & .50 & & .42 & \\
\hline
\end{tabular}

${ }^{*} p<.05 .{ }^{*} p<.01 .{ }^{* *} p<.001$.

Table 6. Logistic Regressions Predicting Outcomes From Strengths and Adversities

\begin{tabular}{|c|c|c|c|c|c|c|c|}
\hline & $\begin{array}{l}\text { Subjective } \\
\text { well-being }\end{array}$ & & $\begin{array}{l}\text { Posttraumatic } \\
\text { growth }\end{array}$ & & & $\begin{array}{l}\text { Mental } \\
\text { health }\end{array}$ & \\
\hline & Odds ratio & $95 \% \mathrm{Cl}$ & Odds ratio & & $95 \% \mathrm{Cl}$ & Odds ratio & $95 \% \mathrm{Cl}$ \\
\hline & & & & Demographics & & & \\
\hline Age & $.97^{* * *}$ & $.96-.98$ & $.99^{*}$ & & $\begin{array}{l}.98- \\
1.00\end{array}$ & 1.01 & $\begin{array}{l}1.00- \\
1.02\end{array}$ \\
\hline Sex & .92 & $\begin{array}{l}68- \\
1.24\end{array}$ & 1.01 & & $\begin{array}{l}.76- \\
1.36\end{array}$ & $.77+$ & $\begin{array}{l}.58- \\
1.00\end{array}$ \\
\hline \multirow[t]{2}{*}{$R^{2}$ demographics only } & .00 & & .01 & & & .04 & \\
\hline & & & & Adversities & & & \\
\hline Financial strain & $.87^{* * *}$ & $.83-.92$ & $1.11^{* * *}$ & & $\begin{array}{l}1.06- \\
1.17\end{array}$ & $.94^{*}$ & $.90-.99$ \\
\hline
\end{tabular}




\begin{tabular}{|c|c|c|c|c|c|c|c|}
\hline Poly-victimization & .97 & $\begin{array}{l}.94- \\
1.01\end{array}$ & 1.00 & & $\begin{array}{l}97- \\
1.03\end{array}$ & $.90^{* * *}$ & $.87-.93$ \\
\hline Adverse life events & $.91^{*}$ & $.85-.97$ & 1.05 & & $\begin{array}{l}99- \\
1.12\end{array}$ & .98 & $\begin{array}{l}.92- \\
1.04\end{array}$ \\
\hline \multirow[t]{2}{*}{$\Delta R^{2}$ adversities added } & .10 & & .00 & & & & \\
\hline & & & & $\begin{array}{l}\text { Resilience portfolio } \\
\text { strengths }\end{array}$ & & & \\
\hline \multirow[t]{2}{*}{ Poly-strengths } & $1.26^{* * *}$ & $\begin{array}{l}1.18- \\
1.35\end{array}$ & $1.15^{* * *}$ & & $\begin{array}{l}1.08- \\
1.23\end{array}$ & $1.06^{*}$ & $\begin{array}{l}1.01- \\
1.12\end{array}$ \\
\hline & & & & Regulatory strengths & & & \\
\hline Endurance & $1.47^{* *}$ & $\begin{array}{l}1.13- \\
1.92\end{array}$ & $1.79^{* * *}$ & & $\begin{array}{l}1.38- \\
2.31\end{array}$ & 1.20 & $\begin{array}{l}.96- \\
1.51\end{array}$ \\
\hline Emotional Awareness & 1.14 & $\begin{array}{l}.92- \\
1.41\end{array}$ & $1.38^{* *}$ & & $\begin{array}{l}1.12- \\
1.70\end{array}$ & $1.30^{* *}$ & $\begin{array}{l}1.10- \\
1.54\end{array}$ \\
\hline Emotional Regulation & .89 & $\begin{array}{l}.75- \\
1.05\end{array}$ & $.83^{*}$ & & $.71-.97$ & $2.47^{* * *}$ & $\begin{array}{l}2.10- \\
2.90\end{array}$ \\
\hline Coping & 1.03 & $\begin{array}{l}.85- \\
1.27\end{array}$ & $1.54^{* * *}$ & & $\begin{array}{l}1.26- \\
1.88\end{array}$ & $.87 .72-$ & 1.04 \\
\hline Honesty and Humility & 1.12 . & $\begin{array}{l}96- \\
1.31\end{array}$ & .95 & & $\begin{array}{l}.82- \\
1.11\end{array}$ & 1.10 & $\begin{array}{l}.94- \\
1.28\end{array}$ \\
\hline \multirow[t]{2}{*}{ Anger Management } & 1.05 & $\begin{array}{l}.85- \\
1.29\end{array}$ & .90 & & $\begin{array}{l}.74- \\
1.11\end{array}$ & .91 & $\begin{array}{l}.76- \\
1.10\end{array}$ \\
\hline & & & & $\begin{array}{l}\text { Meaning-making } \\
\text { strengths }\end{array}$ & & & \\
\hline Purpose 2 & $.16^{* * *}$ & $\begin{array}{l}1.74- \\
2.67\end{array}$ & $1.65^{* * *}$ & & $\begin{array}{l}1.35- \\
2.02\end{array}$ & $1.25^{*}$ & $\begin{array}{l}1.04- \\
1.50\end{array}$ \\
\hline Optimism & $1.19^{*}$ & $\begin{array}{l}1.01- \\
1.39\end{array}$ & .86 & & $\begin{array}{l}.74- \\
1.01\end{array}$ & $1.27^{* *}$ & $\begin{array}{l}1.10- \\
1.47\end{array}$ \\
\hline $\begin{array}{l}\text { Religious meaning- } \\
\text { making }\end{array}$ & 1.06 & $\begin{array}{l}.90- \\
1.24\end{array}$ & $1.55^{* * *}$ & & $\begin{array}{l}1.33- \\
1.80\end{array}$ & .95 & $\begin{array}{l}.82- \\
1.09\end{array}$ \\
\hline $\begin{array}{l}\text { Self-oriented meaning } \\
\text { making }\end{array}$ & .89 & $\begin{array}{l}.75- \\
1.06\end{array}$ & 1.11 & & $\begin{array}{l}.94- \\
1.30\end{array}$ & 1.00 & $\begin{array}{l}.86- \\
1.17\end{array}$ \\
\hline $\begin{array}{l}\text { Relationship-oriented } \\
\text { meaning-making }\end{array}$ & 1.17 & $\begin{array}{l}.92- \\
1.48\end{array}$ & .96 & & $\begin{array}{l}.77- \\
1.20\end{array}$ & .91 & $\begin{array}{l}.75- \\
1.12\end{array}$ \\
\hline Moral meaning-making & $.80^{*}$ & $.65-.97$ & 1.01 & & $\begin{array}{l}.82- \\
1.23\end{array}$ & .98 & $\begin{array}{l}.82- \\
1.16\end{array}$ \\
\hline \multirow[t]{2}{*}{$\begin{array}{l}\text { Family care meaning- } \\
\text { making. }\end{array}$} & $71^{* * *}$ & $.59-.85$ & .84 & & $\begin{array}{l}.71- \\
1.00\end{array}$ & 1.10 & $\begin{array}{l}.93- \\
1.29\end{array}$ \\
\hline & & & & $\begin{array}{l}\text { Interpersonal } \\
\text { strengths }\end{array}$ & & & \\
\hline Generativity & $1.54^{* * *}$ & $\begin{array}{l}1.21- \\
1.96\end{array}$ & 1.15 & & $\begin{array}{l}.92- \\
1.45\end{array}$ & .93 & $\begin{array}{l}.75- \\
1.15\end{array}$ \\
\hline Compassion & .90 & $\begin{array}{l}.72- \\
1.13\end{array}$ & .96 & & $\begin{array}{l}.80- \\
1.15\end{array}$ & $1.49^{* *}$ & $\begin{array}{l}1.18- \\
1.89\end{array}$ \\
\hline $\begin{array}{l}\text { Social support: } \\
\text { Immediate family }\end{array}$ & 1.10 & $\begin{array}{l}.90- \\
1.35\end{array}$ & 1.04 & & $\begin{array}{l}.86- \\
1.26\end{array}$ & 1.08 & $\begin{array}{l}.90- \\
1.30\end{array}$ \\
\hline $\begin{array}{l}\text { Social support: } \\
\text { Friends/adults }\end{array}$ & 1.03 & $\begin{array}{l}.84- \\
1.28\end{array}$ & .94 & & $\begin{array}{l}.77- \\
1.16\end{array}$ & 1.16 & $\begin{array}{l}.97- \\
1.39\end{array}$ \\
\hline Community support & 1.11 & $\begin{array}{l}.95- \\
1.31\end{array}$ & .93 & & $\begin{array}{l}.81- \\
1.09\end{array}$ & 1.01 & $\begin{array}{l}.88- \\
1.17\end{array}$ \\
\hline Forgiveness & 1.11 & $\begin{array}{l}.94- \\
1.31\end{array}$ & .90 & & $\begin{array}{l}.77- \\
1.05\end{array}$ & 1.03 & $\begin{array}{l}.90- \\
1.19\end{array}$ \\
\hline Generous behaviors & 1.05 & $\begin{array}{l}.90- \\
1.23\end{array}$ & .92 & & $\begin{array}{l}.80- \\
1.07\end{array}$ & 1.04 & $\begin{array}{l}.90- \\
1.19\end{array}$ \\
\hline
\end{tabular}




\begin{tabular}{|c|c|c|c|c|c|c|}
\hline Generative roles & .90 & $\begin{array}{l}77- \\
1.06\end{array}$ & .86 & $\begin{array}{l}.74- \\
1.00\end{array}$ & .89 & $\begin{array}{l}.77- \\
1.04\end{array}$ \\
\hline Maternal attachment & .92 & $\begin{array}{l}.78- \\
1.08\end{array}$ & .93 & $\begin{array}{l}.79- \\
1.08\end{array}$ & $.82^{*}$ & $.70-.96$ \\
\hline Paternal attachment & .87 & $\begin{array}{l}.75- \\
1.01\end{array}$ & $.86^{*}$ & $.75-.98$ & .95 & $\begin{array}{l}.83- \\
1.08\end{array}$ \\
\hline $\begin{array}{l}\Delta R^{2} \text { resilience portfolio } \\
\text { strengths added }\end{array}$ & .48 & & .49 & & .23 & \\
\hline Final $R^{2}$ full model & .58 & & .50 & & .42 & \\
\hline $\begin{array}{l}* p<.05 .{ }^{*} p<.01 . * * * \\
p<.001 .\end{array}$ & & & & & & \\
\hline
\end{tabular}

\section{Subjective well-being}

The full model accounted for $58 \%$ of the variance in subjective well-being, most of which (48\%) was due to resilience portfolio factors (see Table 6). Younger age and lower levels of financial strain and stressful life events were associated with greater well-being. Poly-strengths (total number of strengths with above-average scores) was uniquely associated with increased well-being. After accounting for adversities, demographic variables, and poly-strengths, several individual strengths also accounted for unique variance. Among regulatory strengths, higher endurance was associated with more subjective well-being. Among meaning making strengths, higher purpose and optimism were associated with greater subjective well-being. Counter to hypothesis, moral meaning making and family care meaning making had effects in the opposite direction, suggesting these might be sources of stress rather than resilience. Among interpersonal strengths, greater generativity was associated with greater well-being.

\section{Posttraumatic growth}

The full model accounted for $50 \%$ of the variance in subjective well-being, of which almost all unique variance (49\%) was due to resilience portfolio factors. Younger age (marginally) and higher levels of financial strain were associated with greater posttraumatic growth. Poly-strengths was uniquely associated with increased posttraumatic growth. Among regulatory strengths, higher endurance, emotional awareness, and coping were uniquely associated with more posttraumatic growth. Among meaning making strengths, higher purpose and religious meaning making were uniquely associated with greater posttraumatic growth. Among interpersonal strengths, greater compassion was uniquely associated with greater posttraumatic growth. Counter to hypothesis, paternal attachment was correlated in the opposite direction.

\section{Mental health}

The full model accounted for $42 \%$ of the variance in mental health symptoms, but in this case the variance was split more evenly across blocks. Demographic characteristics and adversities together explained $19 \%$ of the variance, which increased to $42 \%$ of the variance when strengths were added. Poly-victimization was most strongly associated with decreased mental health, but financial strain was also significantly associated with poorer mental health. Similar to the findings for subjective well-being and posttraumatic growth, poly-strengths was uniquely associated with better mental health. After accounting for these variables, several individual strengths accounted for unique variance. Among regulatory strengths, higher emotional awareness and emotional regulation were associated with better mental health. Among meaning making strengths, a greater sense of purpose was associated with better mental health, making it the only individual strength that was significant in all three 
models. Optimism was also associated with better mental health. Counter to hypothesis, stronger maternal attachment was associated with worse mental health. No interpersonal strengths accounted for unique variance in the predicted direction.

\section{Discussion}

The primary purpose of this study was to further understanding of how individuals achieve well-being despite experiencing high levels of adversity and is consistent with the emerging literature on "positive deviance," or individuals and families who engage in unusually beneficial behaviors, especially with regard to coping with problems (Marsh et al., 2004; Spreitzer \& Sonenshein, 2004). To this end, we adopted an analytical framework, the resilience portfolio model (Grych et al., 2015) designed to predict true thriving and to distinguish those with above-average levels of well-being from others. We studied predictors of well-being in a large community sample from Appalachia; this was the largest psychological study ever conducted in rural Appalachia, and the data reflect the social and economic struggles faced by this region of the United States. The level of adversity reported in this sample was high. We used the same indicators of financial strain as those used in a nationally representative U.S. study, the National Survey of Children's Exposure to Violence, and each of these financial indicators was higher than in that sample. The rates of victimization and other adversity also was high. In total, 98.5\% of the sample reported at least one form of adversity, supporting the conclusion that to survive to adulthood, at least in this region of the country, means to experience adversity. Yet, despite these disturbingly high rates of adversity, considerable well-being also was reported by participants. This is consistent with other research that acknowledges the extraordinary resilience of many individuals exposed to high burdens of adversity (e.g., Masten, 2015).

The results showed that a portfolio of protective factors accounted for a substantial portion of variance in all three indicators of well-being: subjective well-being, posttraumatic growth, and mental health symptoms. Participants' strengths accounted for more variance than their history of adversity or their social position as represented by the demographic characteristics of gender and age: Hierarchical regressions indicated that adversities and demographics together accounted for $1 \%$ to $19 \%$ of the variance in mental health, subjective well-being, and posttraumatic growth; the change in $R^{2}$ when protective factors were added ranged from $23 \%$ to $49 \%$ (resulting in a total full model $R^{2}$ from $42 \%$ to $58 \%)$. Poly-strengths, representing the number of different types of strengths of which each participant reported above-average levels, explained unique variance in all three outcomes. This construct parallels the concept of poly-victimization and indicates that individuals who have strengths in more areas report healthier functioning. The findings for poly-strengths provide initial empirical support for one element of the resilience portfolio model, which is that the density and diversity of strengths is important to consider, over and above the presence of any particular strength. However, even after accounting for the total number of strengths reported by participants, several individual strengths also accounted for unique variance in health outcome.

Some of the most promising individual protective factors were emotional regulation, emotional awareness, a sense of purpose, optimism, and a newly studied protective factor, psychological endurance, all of which uniquely predicted two or more indices of health. Individuals reporting a greater sense of purpose reported greater subjective well-being and posttraumatic growth and fewer mental health symptoms; emotional regulation and awareness were significantly and uniquely related 
to greater posttraumatic growth and fewer mental health symptoms, optimism was associated with subjective well-being and mental health symptoms, and psychological endurance uniquely predicted subjective well-being and posttraumatic growth. These findings are consistent with prior research on resilience (see Masten, 2015) and also extend the field by demonstrating new associations between well-being and some strengths that have not received prior study. For example, the construct of psychological endurance is important to Apache culture but appears to be absent from the mainstream psychological literature. The Apache concept of enduring strength is similar to but also distinct from constructs such as "grit" (Duckworth, Peterson, Matthews, \& Kelly, 2007). Grit and related concepts such as perseverance tend to be goal-focused and often refer to persisting in the completion of specific tasks (as represented in items on the most commonly used scale), and in these ways reflect a Western approach to understanding persistence in the face of adversity. However, enduring strength in Apache culture involves being a source of psychological strength for your family and your community and staying true to yourself despite setbacks and even victimization. This strength had one of the highest levels of unique variance for two forms of well-being, and suggests that it is valuable to extend the conceptualization of strengths beyond Western culture. It is interesting that in the current study, protective factors like endurance, generativity and compassion emerged in relation to some outcomes. These are factors that have been identified as potential sources of strength in rural Appalachian communities (Gessert et al., 2015; Woodard, 2011).

\section{Strengths and Limitations}

The results of this study should be considered in light of the strengths and limitations of the project. To our knowledge, this is the first study to examine poly-strengths and psychological endurance and one of few to study resilience in residents of Appalachia. Appalachia, one of the largest low-income regions of the United States, is an understudied region that can be hard to access for outsiders (Woodard, 2011) and our large community sample from this area is a strength. However, at the same time, the region has unique demographic characteristics, such as below average income relative to the rest of the United States and less racial and ethnic diversity than many regions of the country. Although our sampling strategy successfully oversampled African Americans and Latinos, it would be valuable to replicate these findings in other groups and in other regions of the country and the world. This was a cross-sectional study, which is an appropriate and cost-effective means of exploring new ideas, but would benefit from replication in a longitudinal study. It included a broad range of ages (from adolescence through middle adulthood), but it would also be valuable to extend the study questions to a sample that included older adults. The issue of shared method variance is also a limitation, and future research could incorporate multiple informants or other data sources. The creation and adaptation of numerous strengths measures for a low-income community sample involving youth as young as age 12 also is a strength. Finally, basing the study on a theoretical framework, the Resilience Portfolio Model (Grych et al., 2015) is a strength, but due to survey length and other resource considerations, we were not able to examine all of the potentially relevant strengths for resilience portfolios. Further work is needed to connect this approach to the larger literature on resilience and to replicate these findings, especially for unexpected findings such as the positive association between financial strain and posttraumatic growth in the multivariate analyses. 


\section{Research Implications}

The results of this study, especially taken in the context of the resilience portfolio model (Grych et al., $\underline{2015}$ ), suggest several avenues for further research. It may be worthwhile to further investigate some of these constructs. For example, better emotional regulation was associated with better mental health, but anger management, one type of emotional regulation, was not. Exploring the particular emotions that are most important to regulate in particular situations could be an important avenue for future research. Some results suggest that more measurement work is needed to better capture the important elements of some constructs. For example, our measure of meaning making through family care may have tapped into caregiving burden more than the joys of giving to family. Although we recognize that caregiving has an element of burden, it is also a willing sacrifice on the part of most family members and a trade-off that is more than made up for in the emotional support and sense of purpose provided. This measure appears not to have adequately captured more positive elements-or our perception of family life could be wrong-but either way further investigation is warranted. Similarly, some of our results regarding attachment were in the unexpected direction, which could perhaps suggest that those items are confounded with help-seeking during distress or some other unanticipated element, especially when the variance common to other interpersonal strengths is partialed out. This also needs further investigation.

Other work can also be done to try to identify the most important strengths that explain well-being after adversity, including the role of poly-strengths. No one has every possible psychological strength and it would be useful to continue exploring whether there is some particular number or balance or whether there are indeed some key strengths that no one should be without. For example, Lenzi et al. (2015) found that for students experiencing victimization by peers, between four and eight seemed to be a key number of individual strengths that created a "tipping point" for avoiding victimization. Given that this is one of the first studies to investigate poly-strengths and one of the largest to compare the relative merits of different strengths in relation to indicators of well-being (Park et al., 2004; Peterson et al., 2007), it is premature to draw firm conclusions about minimum numbers or types. Although there are many more strengths that might be investigated and we encourage exploring additional protective factors, we also encourage researchers to start comparing the relative utility of different strengths and not just catalog "all the adjectives in the dictionary (as we have heard existing research described)." Community-based participatory research, including the use of community member advisory boards, may assist with identifying other key strengths.

\section{Prevention and Intervention Implications}

The findings are consistent with the growing recognition that a strengths-based approach is a powerful avenue not only for understanding well-being after trauma, but also for potentially informing new and more effective prevention and intervention strategies (Hamby \& Banyard, 2017). The effort to identify key strengths in the Resilience Portfolio Model and a minimum set that will best support resilient outcomes would have tremendous prevention and intervention implications. People crave a strengthsbased approach to reducing and coping with adversity (Edwards, Jones, Mitchell, Hagler, \& Roberts, 2016; Hamby \& Banyard, 2017). Existing prevention programs still tend to focus on identifying risk factors and warning signs and teach a fairly restricted set of strengths skills, such as conflict negotiation, which are reasonable ideas, but not evidence-based choices. Even programs that 
emphasize some of the skills that showed promise here, such as social and emotional learning (SEL) programs, do not rely entirely on scientific evidence to guide their program content and may address a narrower range of resilience-promoting factors than suggested by the current study. This is almost certainly one of the reasons why many violence prevention programs and other programs seeking to reduce social problems like substance abuse have very low and even null effect sizes (Finkelhor, Vanderminden, Turner, Shattack, \& Hamby, 2014; Flynn et al., 2015). The current study supported the findings of some previous work that emotional regulation is a key strength, which supports the SEL model (but not some other psychoeducational programs). The findings that a sense of purpose, optimism, and generativity are associated with thriving after adversity suggest fruitful avenues for possible curriculum development that might offer truly new directions to help us meet humanity's longtime goals to reduce the worldwide burden of violence and other adversity and ameliorate the consequences of these experiences when they do occur.

\section{References}

Abt SRBI. (2012). Second National Survey of Children's Exposure to Violence (NatSCEV II): Methods report. Retrieved from https://www.bjs.gov/content/pub/pdf/natscev2 mr.pdf

Amato, P. R. (1990). Personality and social network involvement as predictors of helping behavior in everyday life. Social Psychology Quarterly, 53, 31-43. 10.2307/2786867

Antaramian, S. P., Scott Huebner, E., Hills, K. J., \& Valois, R. F. (2010). A dual-factor model of mental health: Toward a more comprehensive understanding of youth functioning. American Journal of Orthopsychiatry, 80, 462-472. 10.1111/j.1939-0025.2010.01049.x

Ashton, M. C., \& Lee, K. (2009). The HEXACO-60: A short measure of the major dimensions of personality. Journal of Personality Assessment, 91, 340-345. 10.1080/00223890902935878

Bonanno, G. A. (2004). Loss, trauma, and human resilience: Have we underestimated the human capacity to thrive after extremely aversive events?American Psychologist, 59, 20-28. 10.1037/0003-066X.59.1.20

Briere, J. (1996). Trauma Symptom Checklist: Professional manual. Odessa, FL: Psychological Assessment Resources.

Bronfenbrenner, U. (1986). Ecology of the family as a context for human development: Research perspectives. Developmental Psychology, 22, 723-742. 10.1037/0012-1649.22.6.723

Chavis, D. M., \& Wandersman, A. (1990). Sense of community in the urban environment: A catalyst for participation and community development. American Journal of Community Psychology, 18, 55-81. 10.1007/BF00922689

Cicchetti, D., Rogosch, F. A., Lynch, M., \& Holt, K. D. (1993). Resilience in maltreated childrenProcesses leading to adaptive outcome. Development and Psychopathology, 5, 629-647. $10.1017 /$ S0954579400006209

De Marco, A., \& De Marco, M. (2010). Conceptualization and measurement of the neighborhood in rural settings: A systematic review of the literature. Journal of Community Psychology, 38, 99114. 10.1002/jcop.20354

Diener, E., Emmons, R. A., Larsen, R. J., \& Griffin, S. (1985). The Satisfaction With Life Scale. Journal of Personality Assessment, 49, 71-75. 10.1207/s15327752jpa4901_13 
Duckworth, A. L., Peterson, C., Matthews, M. D., \& Kelly, D. R. (2007). Grit: Perseverance and passion for long-term goals. Journal of Personality and Social Psychology, 92, 1087-1101. 10.1037/0022-3514.92.6.1087

Duckworth, A. L., Steen, T. A., \& Seligman, M. E. P. (2005). Positive psychology in clinical practice. Annual Review of Clinical Psychology, 1, 629-651.

10.1146/annurev.clinpsy.1.102803.144154

Edwards, K. M., Jones, L. M., Mitchell, K. J., Hagler, M. A., \& Roberts, L. T. (2016). Building on youth's strengths: A call to include adolescents in developing, implementing, and evaluating violence prevention programs. Psychology of Violence, 6, 15-21. 10.1037/vio0000022

Fergusson, D. M., \& Horwood, L. J. (2003). Resilience to childhood adversity: Results of a 21-year study. In S. S.Luthar (Ed.), Resilience and vulnerability: Adaptation in the context of childhood adversities (pp. 130-155). New York, NY: Cambridge University Press. 10.1017/CBO9780511615788.008

Finkelhor, D., Shattuck, A., Turner, H., Ormrod, R., \& Hamby, S. (2011). Polyvictimization in developmental context. Journal of Child \& Adolescent Trauma, 4, 291-300. 10.1080/19361521.2011.610432

Finkelhor, D., Vanderminden, J., Turner, H., Shattuck, A., \& Hamby, S. (2014). Youth exposure to violence prevention programs in a national sample. Child Abuse \& Neglect, 38, 677-686.

Flynn, A. B., Falco, M., \& Hocini, S. (2015). Independent evaluation of middle school-based drug prevention curricula: A systematic review. Journal of the American Medical Association Pediatrics, 169, 1046-1052. 10.1001/jamapediatrics.2015.1736

Furman, W., \& Buhrmester, D. (2009). Methods and measures: The network of relationships inventory: Behavioral systems version. International Journal of Behavioral Development, 33, 470-478. 10.1177/0165025409342634

Galesic, M., \& Bosnjak, M. (2009). Effects of questionnaire length on participation and indicators of response quality in a web survey. Public Opinion Quarterly, 73, 349-360. 10.1093/poq/nfp031

Gessert, C., Waring, S., Bailey-Davis, L., Conway, P., Roberts, M., \& VanWormer, J. (2015). Rural definition of health: A systematic literature review. BMC Public Health, 15, 378. 10.1186/s12889-015-1658-9

Gordon, K. C., \& Baucom, D. H. (2003). Forgiveness and marriage: Preliminary support for a synthesized model of recovery from a marital betrayal. The American Journal of Family Therapy, 31, 179199. $10.1080 / 01926180301115$

Gratz, K. L., \& Roemer, L. (2004). Multidimensional assessment of emotion regulation and dysregulation: Development, factor structure, and initial validation of the difficulties in emotion regulation scale. Journal of Psychopathology and Behavioral Assessment, 26, 41-54. 10.1023/B:JOBA.0000007455.08539.94

Grych, J., Hamby, S., \& Banyard, V. (2015). The resilience portfolio model: Understanding healthy adaptation in victims of violence. Psychology of Violence, 5, 343-354. 10.1037/a0039671

Hamby, S. (2014). Battered women's protective strategies: Stronger than you know. New York, NY: Oxford University Press.

Hamby, S. (2015). On the use of race and ethnicity as variables in violence research. Psychology of Violence, 5, 1-7. 10.1037/a0038470 
Hamby, S., \& Banyard, V. (2017). Prevention 2.0: Moving beyond lessons learned to new models of youth violence prevention. Monteagle, TN: Life Paths Appalachian Research Center.

Hamby, S., Finkelhor, D., Ormrod, R., \& Turner, H. (2004). The Juvenile Victimization Questionnaire (JVQ): Administration and scoring manual. Durham, $\mathrm{NH}$ : Crimes Against Children Research Center.

Hamby, S., Grych, J., \& Banyard, V. L. (2013). Life paths research measurement packet. Sewanee, TN: Life Paths Research Program.

Hamby, S., Segura, A., Taylor, E., Grych, J., \& Banyard, V. (in press). Meaning making in rural Appalachia: Age and gender patterns in seven measures of meaning. Journal of Happiness and Well-Being.

Hamby, S., Stith, S. M., Grych, J., \& Banyard, V. L. (2013). Anger Management Scale-Brief Trait version. Sewanee, TN: Life Paths Research Program.

Hamby, S., Turner, H. A., \& Finkelhor, D. (2011). Financial strain index. Durham, NH: Crimes Against Children Research Center.

Holahan, C. J., \& Moos, R. H. (1987). Personal and contextual determinants of coping strategies. Journal of Personality and Social Psychology, 52, 946-955. 10.1037/0022-3514.52.5.946

Houston, J., \& Grych, J. (2015). Resilience in youth exposed to violence: Protective factors and underlying mechanisms. Milwaukee, WI: Marquette University.

Kennedy, C., Davidov, D., \& Burrell, C. (2014). Associations between intimate partner violence and health outcomes in a university-affiliated emergency department and urgent care setting in Appalachia. Annals of Emergency Medicine, 64(4), S119. 10.1016/j.annemergmed.2014.07.365

Keyes, C. L. (2007). Promoting and protecting mental health as flourishing: A complementary strategy for improving national mental health. American Psychologist, 62, 95-108. 10.1037/0003066X.62.2.95

Kliewer, W., Cunningham, J. N., Diehl, R., Parrish, K. A., Walker, J. M., Atiyeh, C., . .Mejia, R. (2004). Violence exposure and adjustment in inner-city youth: Child and caregiver emotion regulation skill, caregiver-child relationship quality, and neighborhood cohesion as protective factor. Journal of Clinical Child and Adolescent Psychology, 33, 477-487. 10.1207/s15374424jccp3303_5

Lenzi, M., Furlong, M. J., Dowdy, E., Sharkey, J., Gini, G., \& Altoè, G. (2015). The quantity and variety across domains of psychological and social assets associated with school victimization. Psychology of Violence, 5, 411-421. 10.1037/a0039696

Levin, J. S., Markides, K. S., \& Ray, L. A. (1996). Religious attendance and psychological well-being in Mexican Americans: A panel analysis of three-generations data. The Gerontologist, 36, 454463. 10.1093/geront/36.4.454

Luthar, S. S., Cicchetti, D., \& Becker, B. (2000). The construct of resilience: A critical evaluation and guidelines for future work. Child Development, 71, 543-562. 10.1111/1467-8624.00164

Lyubomirsky, S. (2001). Why are some people happier than others? The role of cognitive and motivational processes in well-being. American Psychologist, 56, 239-249. 10.1037/0003066X.56.3.239

Lyubomirsky, S., King, L., \& Diener, E. (2005). The benefits of frequent positive affect: Does happiness lead to success?Psychological Bulletin, 131, 803-855. 10.1037/0033-2909.131.6.803 
Marsh, D. R., Schroeder, D. G., Dearden, K. A., Sternin, J., \& Sternin, M. (2004). The power of positive deviance. British Medical Journal (Clinical Research Ed.), 329, 1177-1179.

10.1136/bmj.329.7475.1177

Masten, A. S. (2001). Ordinary magic. Resilience processes in development. American Psychologist, 56, 227-238. 10.1037/0003-066X.56.3.227

Masten, A. S. (2007). Resilience in developing systems: Progress and promise as the fourth wave rises. Development and Psychopathology, 19, 921-930. 10.1017/S0954579407000442

Masten, A. S. (2014). Global perspectives on resilience in children and youth. Child Development, 85, 620. $10.1111 /$ cdev.12205

Masten, A. S. (2015). Ordinary magic: Resilience in development. New York, NY: Guilford Press.

Masten, A. S., Burt, K. B., Roisman, G. I., Obradović, J., Long, J. D., \& Tellegen, A. (2004). Resources and resilience in the transition to adulthood: Continuity and change. Development and Psychopathology, 16, 1071-1094. 10.1017/S0954579404040143

Masten, A. S., \& Tellegen, A. (2012). Resilience in developmental psychopathology: Contributions of the Project Competence Longitudinal Study. Development and Psychopathology, 24, 345-361. 10.1017/S095457941200003X

McAdams, D. P., \& de St. Aubin, E. (1992). A theory of generativity and its assessment through selfreport, behavioral acts, and narrative themes in autobiography. Journal of Personality and Social Psychology, 62, 1003-1015. 10.1037/0022-3514.62.6.1003

Mccullough, M. E., Emmons, R. A., \& Tsang, J. A. (2002). The grateful disposition: A conceptual and empirical topography. Journal of Family and Social Psychology, 82, 112-127. 10.1037/00223514.82.1.112

Moffitt, T. E., Arseneault, L., Belsky, D., Dickson, N., Hancox, R. J., Harrington, H., . . Caspi, A. (2011). A gradient of childhood self-control predicts health, wealth, and public safety. Proceedings of the National Academy of Sciences of the United States of America, 108, 2693-2698. 10.1073/pnas.1010076108

Pargament, K. I., Smith, B. W., Koenig, H. G., \& Perez, L. (1998). Patterns of positive and negative religious coping with major life stressors. Journal for the Scientific Study of Religion, 37, 711725. 10.2307/1388152

Park, N., Peterson, C., \& Seligman, M. E. P. (2004). Strengths of character and well-being. Journal of Social and Clinical Psychology, 23, 603-619. 10.1521/jscp.23.5.603.50748

Peterson, C., Park, N., Pole, N., D'Andrea, W., \& Seligman, M. E. P. (2008). Strengths of character and posttraumatic growth. Journal of Traumatic Stress, 21, 214-217. 10.1002/jts.20332

Peterson, C., Ruch, W., Beermann, U., Park, N., \& Seligman, M. E. (2007). Strengths of character, orientations to happiness, and life satisfaction. The Journal of Positive Psychology, 2, 149-156. 10.1080/17439760701228938

Peterson, C., \& Seligman, M. E. P. (2004). Character strengths and virtues: A handbook and classification. New York, NY: Oxford University Press.

Pommier, E. A. (2011). The Compassion Scale. Dissertation Abstracts International Section A: Humanities and Social Sciences, 72, 1174.

Putney, S., \& Middleton, R. (1961). Dimensions and correlates of religious ideologies. Social Forces, 39, 285-290. 10.2307/2573423 
Sabina, C., \& Banyard, V. (2015). Moving toward well-being: The role of protective factors in violence research. Psychology of Violence, 5, 337-342. 10.1037/a0039686

Sampson, R. J., Raudenbush, S. W., \& Earls, F. (1997). Neighborhoods and violent crime: A multilevel study of collective efficacy. Science, 277, 918-924. 10.1126/science.277.5328.918

Scheier, M. F., Carver, C. S., \& Bridges, M. W. (1994). Distinguishing optimism from neuroticism (and trait anxiety, self-mastery, and self-esteem): A reevaluation of the Life Orientation Test. Journal of Personality and Social Psychology, 67, 1063-1078. 10.1037/0022-3514.67.6.1063

Spitzberg, B., \& Cupach, W. (2008). Managing unwanted pursuit. In M.Motley (Ed.), Studies in applied interpersonal communication (pp. 3-25). Thousand Oaks, CA: SAGE.

Sprecher, S., \& Fehr, B. (2005). Compassionate love for close others and humanity. Journal of Social and Personal Relationships, 22, 629-651. 10.1177/0265407505056439

Spreitzer, G. M., \& Sonenshein, S. (2004). Toward the construct definition of positive deviance. American Behavioral Scientist, 47, 828-847. 10.1177/0002764203260212

Steger, M. F., Frazier, P., Oishi, S., \& Kaler, M. (2006). The meaning in life questionnaire: Assessing the presence of and search for meaning in life. Journal of Counseling Psychology, 53, 80-93. 10.1037/0022-0167.53.1.80

Stith, S. M., \& Hamby, S. L. (2002). The anger management scale: Development and preliminary psychometric properties. Violence and Victims, 17, 383-402. 10.1891/vivi.17.4.383.33683

Tedeschi, R. G., \& Calhoun, L. G. (1996). The Posttraumatic Growth Inventory: Measuring the positive legacy of trauma. Journal of Traumatic Stress, 9, 455-471. 10.1002/jts.2490090305

Thoits, P. A. (2011). Mechanisms linking social ties and support to physical and mental health. Journal of Health and Social Behavior, 52, 145-161. 10.1177/0022146510395592

Turner, H. A., Finkelhor, D., \& Ormrod, R. (2010). Poly-victimization in a national sample of children and youth. American Journal of Preventive Medicine, 38, 323-330. 10.1016/j.amepre.2009.11.012

Turner, H. A., Shattuck, A., Hamby, S., \& Finkelhor, D. (2013). Community disorder, victimization exposure, and mental health in a national sample of youth. Journal of Health and Social Behavior, 54, 258-275. 10.1177/0022146513479384

Ungar, M. (2013). Resilience, trauma, context, and culture. Trauma, Violence \& Abuse, 14, 255-266. $10.1177 / 1524838013487805$

U.S. Air Force. (2011). 2011 Air Force Community Assessment Survey: Survey data codebook. Lackland Air Force Base, TX: Author.

Woodard, C. (2011). American nations: A history of the eleven rival regional cultures of North America. New York, NY: Penguin.

Zimet, G. D., Dahlem, N. W., Zimet, S. G., \& Farley, G. K. (1988). The Multidimensional Scale of Perceived Social Support. Journal of Personality Assessment, 52, 30-41. 10.1207/s15327752jpa5201_2

This publication is protected by US and international copyright laws and its content may not be copied without the copyright holders express written permission except for the print or download capabilities of the retrieval software used for access. This content is intended solely for the use of the individual user. 
Source: Psychology of Violence. Vol. 8. (2), Mar, 2018 pp. 172-183)

Accession Number: 2017-27398-001

Digital Object Identifier: 10.1037/vio0000135 